\title{
Hydrologic and cost benefit analysis at local scale of streambed recharge structures in Rajasthan (India) and their value for securing irrigation water supplies
}

\author{
Y. Dashora ${ }^{1}$ (D) P. Dillon ${ }^{2}$ - B. Maheshwari ${ }^{3}$ - P. Soni ${ }^{4} \cdot$ H. K. Mittal ${ }^{1} \cdot$ R. Dashora ${ }^{1}$ - P. K. Singh ${ }^{1} \cdot$ R. C. Purohit ${ }^{1}$. \\ P. Katara ${ }^{1}$
}

Received: 9 July 2018 / Accepted: 18 February 2019 / Published online: 25 April 2019

(C) The Author(s) 2019

\begin{abstract}
A hydrological study of four streambed recharge structures, locally called check dams, in a monsoonal area of hard-rock terrain in Rajasthan, India, was conducted over 3 years to evaluate their contribution to agricultural production. Their catchment area totalled 3,003 ha, and mean annual recharge from the 4 impoundments was $779,000 \mathrm{~m}^{3}$ or $26 \mathrm{~mm}$. The calculated components of the annual water balance of these check dams are presented, together with a sensitivity analysis on unmeasured parameters and documentation of capital and maintenance costs of check dams. The maximum recharge was found to occur in the wettest year for the two structures on first-order streams; however, for the two structures on second-order streams, the maximum recharge occurred in the average rainfall year because, at these sites, groundwater levels rose so that the stream became hydraulically connected to the aquifer for a period in the wettest year causing mean dry weather infiltration rates to diminish. The study also evaluated the effect of manual desilting and mechanical desilting on mean dry-weather-infiltration rate. For the check dam that was manually desilted, the recharge increased by $84 \%$ over that of the preceding year, whereas for the mechanically desilted check dam it reduced by $18 \%$, and the two control check dams increased by $13 \%$. A present value analysis for net benefits of additional crop production attributable to recharge from check dams indicated that, after accounting for average annual maintenance costs $2.9 \%$ of capital costs, the benefit:cost ratio of the four check dams averaged 4.1. Hence this study shows that these check dams are economically attractive at the local level for securing irrigation water supplies.
\end{abstract}

Keywords Check dam $\cdot$ Groundwater recharge/water budget $\cdot$ Cost benefit analysis $\cdot$ Artificial recharge $\cdot$ India

Y. Dashora

dashora.yogita@gmail.com

P. Dillon

pdillon500@gmail.com

B. Maheshwari

b.maheshwari@westernsydney.edu.au

P. Soni

prahladsoni.baif@gmail.com

1 Maharana Pratap University of Agriculture and Technology, Udaipur, India

2 CSIRO Land \& Water, and NCGRT, Flinders University, Adelaide, Australia

3 Western Sydney University, Penrith, New South Wales, Australia

4 Vidya Bhawan Krishi Vigyan Kendra, Udaipur, India

\section{Introduction}

Recharge structures in beds of ephemeral streams have been relied on in major programs in the last 60 years for augmenting groundwater recharge in hard-rock aquifers for irrigation and drinking water supplies in many semi-arid and arid countries (Dillon et al. 2019). The high level of investment and high reliance placed on such structures has resulted in much anecdotal testimony by farmers and governments as to their effectiveness, but only 10 studies were found to quantify the recharge attributable to only 18 of these structures in India (Dashora et al. 2018). This paper extends from previous work by exploring factors affecting variations in infiltration rates among four check dams in southern Rajasthan, India, over 3 years, including the effects on groundwater levels measured in nearby wells. It has enabled water balances of these check dams to be calculated, including the annual recharge. 
It is known that some recharge structures have impoundments that in some cases are well-scoured by high flows and therefore do not accumulate much silt. Other check dams accumulate silt that settles out in the check dam reducing the capacity of the impoundment and likely also reducing the permeability of streambed sediments, and hence the rate of infiltration of water. Desilting of check dams is desirable in such cases, but until now there has been no study in india of the impact of desilting of check dams on infiltration rates. This paper includes a study of two types of desilting, by manual labour and by heavy mechanized equipment, and compares the impacts.

Finally, there is sparse reliable information on the local economic impacts of streambed recharge structures (e.g. CGWB 2000, 2007), which this paper attempts to address. The methodology proposed by CGWB (2000) assumes a "command area" where crop production is attributed, wholly or in part, to the groundwater recharged by a nearby streambed structure. It is difficult to gain scientific evidence for the extent of the impacted area so the exercise, while commendable, remains somewhat subjective. In this paper a different approach is adopted. Recharge is measured from each check dam over a 3-year time period and the capital costs and maintenance costs are both taken into account through a present value analysis, that then gives a unit cost of recharged water. The benefits are determined by considering the net profit from agricultural production, after accounting for production costs and using local information on yields, prices and water use requirements of major crops; therefore, knowing the local mix of crop types leads to a unit benefit of water for irrigation. An assumption is made that all of the recharged water results in additional water supply to crops and in the Dharta catchment studied in southern Rajasthan, which contains 250 monitoring wells read weekly over 3 years (Maheshwari et al. 2014; Chinnasamy et al. 2018a), this is a well-supported assumption. The ratio of unit benefit to unit cost therefore provides an alternative approach to calculation of the benefit:cost ratio of recharge structures.

\section{Materials and methods}

\section{Study area}

The Dharta watershed with an area of 6,305 ha is situated in a gently undulating part of the Aravalli Hills of Udaipur District in southern Rajasthan, about $65 \mathrm{~km}$ east of the city of Udaipur. Mean annual rainfall at the nearby Vallabhnagar meteorological station (1973-2016) is $665 \mathrm{~mm}$ with more than $90 \%$ falling in the monsoon season (June-October). The area has a number of villages with a population of 18,600 (as per census 2011) that relies on groundwater for drinking water supplies and for livelihood from growing agricultural crops. Kharif (monsoon season crop), which is mainly maize (food grain) followed by guar (cluster bean), jowar (sorghum: fodder and seed) and soybean (oilseed), are generally grown without irrigation except if there are dry periods, when so-called "lifesaving" groundwater irrigation is applied. The rabi season (dry winter) crop depends on irrigation from farmers' wells and only one quarter to one half of the catchment area is irrigated. The main rabi crops are wheat, mustard and isabgol (psyllium husk). Having no surface-water supply source, the irrigated area is limited by the availability of groundwater which varies from year to year based on post-monsoon groundwater storage.

Prior to the $1960 \mathrm{~s}$, irrigation water was accessed from large-diameter dug wells with water lifted in buckets powered by oxen walking down ramps. When electricity supply commenced in the 1960s, pumps were installed, the cropped area rapidly expanded, and groundwater levels fell. Wells were deepened from $\sim 10$ to $\sim 30 \mathrm{~m}$ (from farmer interviews and observations). The introduction of tube well construction in the 1980s helped sustain production but continued to lower the dry-season water table leading to unreliability of dug wells (Shah 2009; Shankar et al. 2011). To help enhance groundwater recharge, over the last four decades check dams have been constructed by government agencies and nongovernment organizations in ephemeral wadis of western and southern parts of India (Agoramoorthy and Hsu 2008; Kulkarni et al. 2015).

The geology of the Udaipur District is dominated by phyllite-schist and also consists of gneiss, granite and quartzite. Typically, hard-rock aquifers are unconfined within $100 \mathrm{~m}$ of the surface (Rajasthan Ground Water Department 2008), and confined deeper aquifers are present in some locations. Machiwal (2009) records that hydraulic conductivity of hardrock unconfined aquifers in Udaipur district ranges from 1 to $40 \mathrm{~m} /$ day. Chinasamy et al. (2018a) estimated an average specific yield value in Dharta watershed between 1.4 and $8 \%$ with an average of $4 \%$.

In this catchment, depth to groundwater level was observed weekly from 250 wells between 2013 and 2016. Groundwater levels were recorded by 25 farmers who had been selected and trained to take hydrological measurements and were known as Bhujal Jankaars or BJs (groundwater knowledge brokers; Maheshwari et al. 2014; Jadeja et al. 2018). Four check dams, near the villages of Badgaon, Dharta, Hinta and Sunderpura, were selected for detailed study. These are located on first and second order streams (Fig. 1).

The objectives of this paper are to demonstrate the hydrological performance of these four check dams over a 3-year period, to report their localized economic impact and thereby produce a cost-benefit analysis, as well as to compare effects of manual and mechanized scraping of silt from check dams on their recharge performance. Results are intended to inform planning and policies for streambed recharge structures in similar areas. This will enable them in conjunction with demand management to sustain and maximise livelihoods (Dillon et al. 2009). 


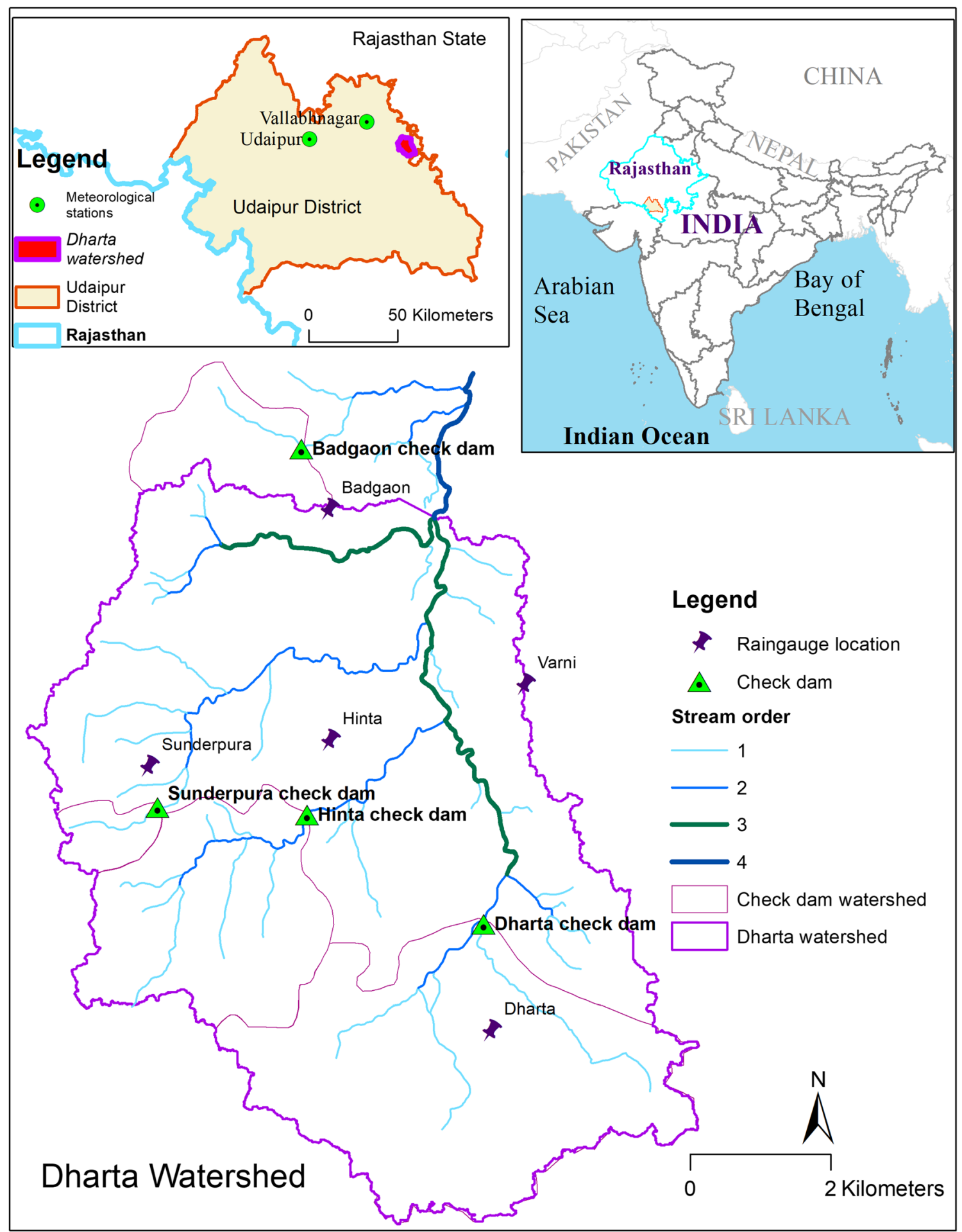

Fig. 1 Location map of the study area (from Dashora et al. 2018)

\section{Recharge estimation}

The monitoring and recharge estimation of four check dams for 3 years (2014-2016) was done as described for the 2014 and 2015 years in Dashora et al. (2018) using a simple daily water balance method applied to the water impounded by each check dam. In summary, for each check dam, the area- and volume- elevation curves had been determined from a survey of topographic level. During dry weather, the measured daily decline in the impounded water level was attributed to the dryweather-infiltration rate (DWIR) and evaporation, where evaporation was estimated as a uniform $5 \mathrm{~mm} /$ day, by scaling 
from the mean daily evaporation in the A-class pan evaporimeter at CTAE, Udaipur meteorological station (Dashora et al. 2018). There was no direct use of water from check dams. During wet weather, when levels remained below the spillway, inflows were calculated using water level change accounting for mean DWIR (over the period in that year when the check dam contained water) rainfall and evaporation - that is, the volume of daily recharge in wet weather was assumed to occur at the mean DWIR multiplied by the average surfacewater area over the day, and did not depend on estimated inflow. When the water level exceeded the cease-to-flow level of the spillway, the instantaneous discharge rate was calculated using a weir discharge formula for a horizontal broadcrested weir. The average of the flow rates for the current and preceding days was assumed to occur over the full $24 \mathrm{~h}$ to crudely estimate the daily spill and this was added to the calculated inflow. The discharge coefficient in the weir formula was adjusted to constrain seasonal runoff coefficients to physically plausible values. Spill volumes and inflow during spill were expected to be unreliable and were not used in the calculation of recharge (Dashora et al. 2018).

A sensitivity analysis was performed to assess the impacts on water balance components of evaporation rate, weir discharge coefficient and also the mean dry weather infiltration rate (MDWIR) as applied during wet weather. In order to interpret factors that may affect DWIR, the groundwater levels from the three closest monitoring wells to each check dam were recorded daily during periods when water was impounded and weekly at other times. Also, the recorded mean daily air temperature at Udaipur meteorological station was obtained.

\section{Desilting measurements}

Check dams accumulate any silt that is not discharged over the spillway. Such silt impairs the performance of check dams in two ways. Firstly, it reduces the storage capacity of the check dam so its ability to retain and recharge water is diminishedas an example, it was observed in 2013 that one 5-year-old, 2m-deep check dam in Gujarat had filled completely with silt, an accumulation averaging $40 \mathrm{~cm} /$ year. More data are needed to determine average siltation rate and its relationship to catchment conditions and check dam location and design, and to estimate typical frequency of desilting needed.

Secondly, the silt retained in the check dam is likely to have a finer particle size distribution than the alluvial sediments in the stream deposited under higher water velocities before the check dam was installed. Hence, accumulation of lower permeability sediment on the floor of the check dam is likely to reduce infiltration rate over time.

Other types of maintenance occasionally required include repairs to concrete weirs, side walls, and aprons to prevent leakage of water through or around the structure, and to ensure its structural integrity. Hence maintenance should be considered an integral part of establishing check dams if they are to continue to perform as expected. In the Dharta catchment, the watershed department had given priority to building new check dams over maintenance of existing check dams, in the absence of information on the effects of siltation and desiltation on recharge.

As part of this study, two methods of removing silt from check dams in the dry season were employed; hand scraping and mechanical scraping (Fig. 2), to determine the effect of these methods on mean dry-weather-infiltration rates (MDWIRs). At Badgaon before the 2015 monsoon, scraping of silt by manual labour was undertaken; note, this was the only check dam studied to be scraped by hand. At the same time, mechanical scraping of Dharta check dam was performed using a bucket excavator. In the following year Dharta check dam was again scraped with machinery along with the Hinta check dam. Both these check dams also received repairs to wing walls before the 2016 monsoon. On each occasion the volume of silt removed was recorded from the number of trolleys of silt removed for each day of desilting, multiplied by the typical volume of silt removed in each trolley. This was also used to give the contracted cost of desilting that was added to any other costs of maintenance.

\section{Assessment of costs of managed aquifer recharge}

The costs of managed aquifer recharge (MAR) structures include capital and maintenance costs. The construction dates and costs of the recharge structures were provided by the Udaipur District Watershed Department (for Dharta and Badgaon check dam), a nongovernmental organisation (NGO; for Sunderpura check dam) and by the Irrigation Department (for Hinta). No costs were attributed to the land inundated or occupied by the check dams because the ponding area of most check dams is under pasture or forest land already in government possession.

The maintenance costs were provided by the Watershed Department and these were costs charged by contractors for mechanical methods of desilting. At one site desilting was performed by farmers and local pottery makers using hand labour and at the others it was performed by mechanical excavator. The volume of silt removed was determined by counting trailer loads moved and estimating the capacity of each trailer.

Operating costs such as annual inspections for structural damage, are very small per check dam in comparison with maintenance costs and were neglected. Also, the cost of monitoring to assess the recharge effectiveness of check dams was neglected. A simple gaugeboard template is available to easily paint gaugeboards onto sidewalls to enable farmer measurements of groundwater levels. There is also a free mobile phone app (MyWell; Daly et al. 2018) to enable BJs to upload daily 
Fig. 2 Desilting methods used for check dams before the 2015 and 2016 monsoons: a manual desilting of Badgaon check dam before 2015 monsoon, b mechanical desilting of Hinta check dam
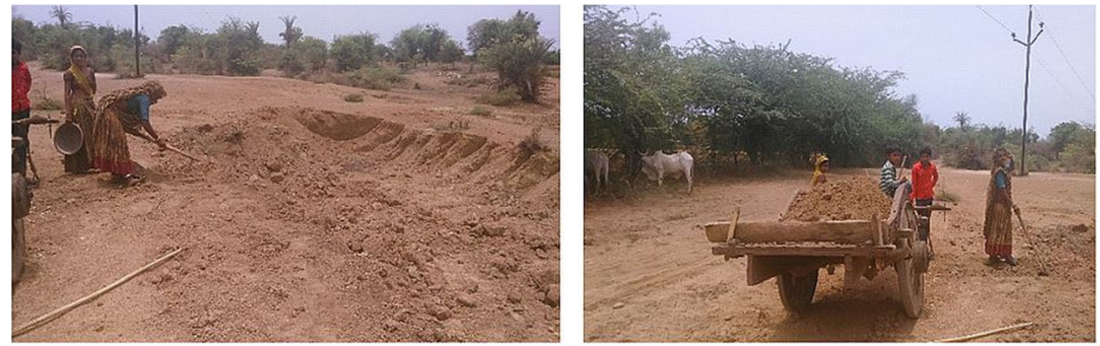

(a)
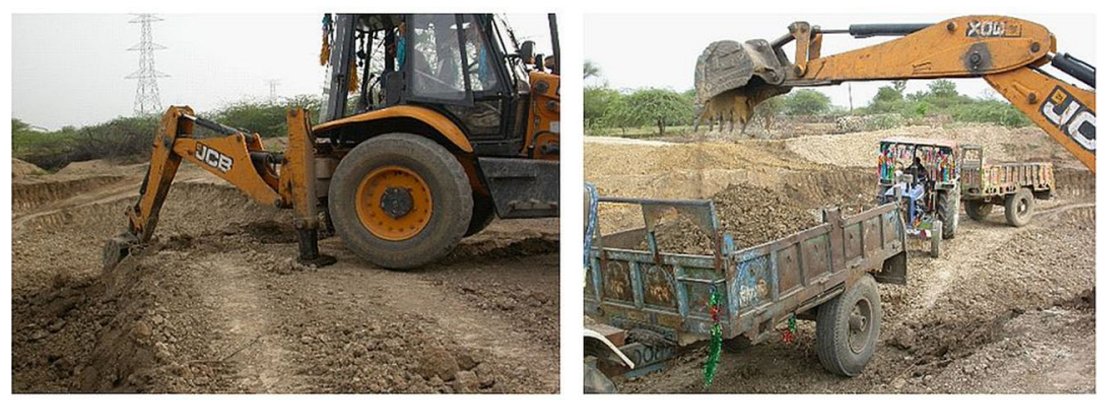

(b)

water level readings (and photographs of the gauge board) to a web site to allow checking and help if required with estimating MDWIR, to thereby assess the need for desilting. Training programs for BJs at a large scale are under consideration by the Government of India, and check dam monitoring is intended to be included in that program.

A present value analysis of costs and benefits was used to determine the benefit:cost ratio. All costs and benefits were discounted to the year 2014. The average Consumer Price Index for India over the last 10 years is $8.1 \%$ and over the last 30 years is $7.7 \%$, so a discount rate $(r)$ of $8 \%$ was adopted (Inflation 2017). The present value of capital costs, PVC, in year 2014 Indian Rupees (INR), is

$\mathrm{PVC}=C_{\mathrm{i}} \times(1+r)^{\left(n_{\mathrm{b}}-n_{\mathrm{i}}\right)}$

where $C_{\mathrm{i}}$ is the initial capital cost expended in INR in the year of construction $\left(n_{\mathrm{i}}\right)$ and $n_{\mathrm{b}}$ is the base year for present value calculation, i.e. 2014.

The annualized present value for check dam construction costs, AC, is given by multiplying the present value of the capital costs by the capital cost recovery factor (CRF). This gives the annualized payment over the life of an asset that has the same present value as the capital cost of the recharge structure.

$\mathrm{AC}=\mathrm{PVC} \times r(1+r)^{L} /\left[(1+r)^{L}-1\right]$

where $L$ is the assumed economic life in years of the recharge structure for the level of maintenance provided. In this paper, asset life of 30 years was assumed, as typical of a concrete structure, possibly conservatively, as many check dams older than 50 years can be found in hard rock areas of India.

Noting the highly irregular and inconsistent maintenance undertaken on the four observed check dams, as reported later, the gross maintenance costs for each check dam were first converted to present value in year 2014 (INR) and then divided by the age of the check dam to produce a mean annual cost of maintenance.

$\mathrm{AM}=\sum_{j} M_{j} \times(1+r)^{\left(n_{\mathrm{b}}-n_{j}\right)} /\left(n_{\mathrm{b}}-n_{\mathrm{i}}\right)$

where $M_{j}$ is the maintenance cost expended in year $n_{j}$, noting that $n_{\mathrm{b}}-n_{j}$ is negative when $n_{j}$ is after 2014 .

The mean of these for the four check dams (MAM) was then adopted as the annual cost in the present value analysis for each of these check dams, so as to be consistent with gross maintenance costs, but smooth out the ad-hoc way they were accrued for these four check dams.

Hence, the annuity to cover construction and maintenance costs for each check dam is given by ACM, where

$\mathrm{ACM}=\mathrm{AC}+\mathrm{AM}$

The average recharge occurring from a check dam over the three years, when used to approximate the mean annual recharge (MR) allows calculation of the average unit cost of annual recharge, $\mathrm{CR}\left(\mathrm{INR} / \mathrm{m}^{3}\right)$ :

$\mathrm{CR}=\mathrm{ACM} / \mathrm{MR}$ 
This can be directly compared with the annual benefits per unit of check dam recharge.

\section{Assessment of MAR benefits}

The benefits were determined using the calculated recharge volumes from each of the four check dams in each year, and the average recharge for each check dam over the 3 years was presumed to approximate the mean annual recharge over the working life of the check dam. There are reasons to believe that this was a representative period of record, having a "typical" year, a "dry" year and a "wet" year; additionally, it was found that wet years do not necessarily result in higher recharge from check dams as will be shown later. It was also assumed that all the recharge from the check dams results in additional agricultural production at the average ratio of crop yield to irrigation water use. This assumption warrants more detailed inspection.

Firstly, there would have been some recharge from the streambed before the check dam was built, so not all the recharge measured can be attributed to the investment in the check dam. However as will be seen later, the duration of wetting and area wetted are both significantly greater with a check dam than without, so the approximation that recharge measured is similar to the net increase due to the check dam appears valid.

Secondly, in this area, groundwater is generally used throughout the rabi season until the well runs dry. Large diameter wells and deep tube wells in hard-rock aquifers are both pumped at a higher rate than the rate at which they are replenished from aquifer storage, so as the rabi season progresses, wells run dry during the daily cycle of up to $8 \mathrm{~h}$ pumping per day, and partially recover when pumping stops. In pumped dug wells, the rate of recovery of the water table, the elevation of the recovered water table, and the daily volume of water extractable, each decline during the course of the rabi irrigation season. Groundwater levels in pumped dug wells were found to reach similar levels at the end of each rabi season, suggesting that groundwater available for crop irrigation was determined by recharge during the preceding monsoon. Lateral gradients of groundwater are shallow in comparison with the drawdown cones observed in irrigation areas, and the high density of wells ensures that a high proportion of any recharge, natural or managed, will contribute to groundwater supplies in the year of recharge.

Thirdly, although the recharge from check dams was found to reduce the salinity of nearby groundwater (Vidya Bhawan Krishi Vigyan Kendra (Udaipur), unpublished data, 20152016), there are no data in the Dharta catchment as yet to differentiate the effects of water quality and quantity on the increase in agricultural productivity. Conversely, sources of water for natural recharge and check dams have the same origin, so there is not anticipated to be a material decline in quality of groundwater used for drinking water supplies, and the risk management measures are likely to be unchanged (Dillon et al. 2014), although intermittent increases in pathogen numbers and changes in fluoride concentrations could potentially occur in nearby wells.

The benefits were calculated using data sourced as follows:

1. Government records at Vallabhnagar Tehsil office provided the area of each crop in each year 2014-2016 within the 6,305-ha Dharta catchment. The average area, $A_{i}($ ha), of each crop $(i)$ in this time period was used to calculate the average proportion of cropped area of each crop type $\left(f_{i}\right)$.

2. The Agricultural Statistics Section of the Directorate of Economics and Statistics, Department of Planning, Jaipur, Rajasthan (Directorate of Economics and Statistics 2017) provided the following:

- The average yield of each crop type in this area, 20112014, $Y_{i}(\mathrm{~kg} / \mathrm{ha})$

- Average price for each crop type in year $2014, P_{i}(\mathrm{INR} / \mathrm{kg})$

- Average production cost for each crop type in year 2014, $C_{i}$ (INR/ha)

- Average irrigation water use of each crop type, $U_{i}\left(\mathrm{~m}^{3} / \mathrm{ha}\right.$; for most crop types) with remaining crop water uses from sources defined later.

This enabled the calculation of the net revenue attributable to the volume of water recharged for the average crop mix grown in the area serviced by all four check dams. There was no attempt to estimate the "command" area influenced by each check dam as the piezometric responses to natural recharge and check dams were confounded, and water quality was not a useful discriminator between water sources.

The crop area weighted mean annual benefit of all agricultural production over the 3 years is.

$\mathrm{MAB}=\sum_{i} f_{i}\left(Y_{i} P_{i}-C_{i}\right)$

The crop area weighted mean water requirement to produce this benefit is given by MAU

$\mathrm{MAU}=\sum_{i} f_{i} U_{i}$

Hence, the annual benefit per unit of volume attributable to recharge from a check dam, BR $\left(\mathrm{INR} / \mathrm{m}^{3}\right)$ is assumed to be at the average benefit per unit of water use, given by:

$\mathrm{BR}=g \mathrm{MAB} / \mathrm{MAU}$

where $g$ is the proportion of recharge from check dams that results in additional agricultural production. In this case, $g$ is assumed to be 1.0 on the basis of the local hydrogeological 
setting as previously discussed. And for the benefit:cost ratio of check dams, BCR is given by the ratio of annual unit benefits and annual unit costs:

$\mathrm{BCR}=\mathrm{BR} / \mathrm{CR}$

\section{Results and discussion}

\section{Hydrological analysis}

\section{Water balance}

The surveys of check dam impoundments allowed calculation of basic metrics for each check dam, as shown in Table 1. Components of the daily water balances for these four check dams in 2016 are plotted in Fig. 3.

Water balance components for the four check dams are summarized for each of 3 years in Table 2. Rainfall in 2016 averaged twice as much as for the two preceding years and generated $72 \%$ of the estimated check dam inflows over the 3 years. Although average rainfall totals in 2014 and 2015 were almost identical, there were significant differences in the temporal and spatial distribution of rainfall that led to estimated runoff of 22 and $6 \%$ of the 3 -year total in those years respectively. Hence estimated inflows relate closely to farmers perceptions that 2014 was an "average" year, 2015 a "dry" year and 2016 a "wet" year. In total across sites and years, $76 \%$ of estimated inflow was spilled, $19 \%$ was recharged and $5 \%$ evaporated. The estimated proportion of inflow that was recharged from all check dams was 37, 70 and $10 \%$ for 2014 , 2015 and 2016 respectively. Conversely spill accounted for 57,18 and $87 \%$ of inflow and evaporation for 7, 16 and 3\% over these years. Total annual recharge from the four check dams in these years was estimated to be $976,000,510,000$ and $850,000 \mathrm{~m}^{3}$ respectively.

The recharge to capacity ratio varied between check dams and years, with a mean of 1.66 and range from 0.17 to 3.40 .
Among years, the mean recharge to capacity ratio for all four check dams ranged from 1.09 in the "dry" year (2015), 1.81 in the "wet" year (2016), to 2.08 in the "average" year (2014), with a coefficient of variation of 0.31 . (These values differ slightly from those reported by Dashora et al. (2018), which was the mean of the individual check dam ratios, rather than the ratio of the totals.) Although the check dams contained water for a longer period in the wet year, the mean infiltration rate was lower than in the other years. The reasons for this include possible hydraulic connection between check dams and aquifers, and high sediment loadings due to intense rainfall events up to $250 \mathrm{~mm}$, and are discussed later in the paper. Among check dams, the ratio of average annual recharge to check dam capacity over the 3 years ranged from 1.01 at Sunderpura (with the highest ratio of detention capacity to catchment area) to 2.48 at Badgaon.

The ratio of recharge to runoff, as expected in the "average" year 2014, was ranked in the same order as the ratio of check dam capacity to catchment area, and approximately so in other years. In general, in the low flow year the proportion of flow recharged (except for Badgaon) increased but in 2016, the "wet" year, the proportion of recharge to inflow declined, as expected for all check dams. Changes in the catchment upstream of Hinta check dam occurred (under Mukhyamantri Jal Swawlamban Yojna) in 2016 which may have contributed to an apparently reduced runoff relative to other catchments.

This shows that there are large season-dependent variations in the hydrologic impacts of check dams. Their impact will be felt greatest in relation to natural recharge in dry years, and at these times, the reduced spill could be conspicuous for downstream communities. The results suggest that longer-term studies are required in order to produce reliable conclusions on long-term or average performance of check dams. In this study, by good fortune, rainfall patterns were favourable, including dry, average and wet years, but this cannot generally be relied upon in design of recharge studies. Furthermore, an economic

Table 1 Check dam dimensions in relation to catchment area (adapted from Dashora et al. 2018)

\begin{tabular}{lllllllll}
\hline $\begin{array}{l}\text { Site } \\
\text { No. }\end{array}$ & $\begin{array}{l}\text { Recharge } \\
\text { structure }\end{array}$ & $\begin{array}{l}\text { Total depth } \\
(\mathrm{m})\end{array}$ & $\begin{array}{l}\text { Water spread } \\
\mathrm{area}^{\mathrm{b}}\left(\mathrm{m}^{2}\right)\end{array}$ & $\begin{array}{l}\text { Capacity } \\
\left(\mathrm{m}^{3}\right)\end{array}$ & $\begin{array}{l}\text { Catchment } \\
\text { area (ha) }\end{array}$ & $\begin{array}{l}\text { Stream } \\
\text { Order }\end{array}$ & $\begin{array}{l}\text { Check dam area } \\
\text { as \% of its catchment } \\
(\%)\end{array}$ & $\begin{array}{l}\text { Check dam capacity }^{\mathrm{b}} \\
\text { as mm over catchment } \\
(\mathrm{mm})\end{array}$ \\
\hline 1 & Badgaon & 1.57 & 39,000 & $42,000^{\mathrm{c}}$ & 338 & 1 & 1.15 & 12.4 \\
2 & Dharta & 1.82 & 136,600 & $140,000^{\mathrm{c}}$ & 1,705 & 2 & 0.80 & 8.2 \\
3 & Hinta & 2.62 & 127,200 & 223,000 & 851 & 2 & 1.49 & 26.2 \\
4 & Sunderpura & 2.05 & 62,800 & 64,400 & 109 & 1 & 5.77 & 59.1 \\
\hline
\end{tabular}

${ }^{a}$ Depth from weir crest to concrete apron at streambed level which is the base of the gaugeboard

${ }^{\mathrm{b}}$ Calculated from area-elevation and volume-elevation curves when water elevation is at the weir crest

${ }^{\mathrm{c}}$ Mean of pre- and post-scraping volumes 
Fig. 3 Water balance plots for the four check dams - Badgaon, Dharta, Hinta and Sunderpurain year 2016. Each plot shows rainfall and storage volume history in the check dam. The flux components are shown as cumulative volumes, inflow, spill, recharge and evaporation. The dashed line indicates the capacity of the check dam (the volume above which spill would occur). Water balance methodology and results for the same check dams in 2014 and 2015 are presented by Dashora et al. (2018)
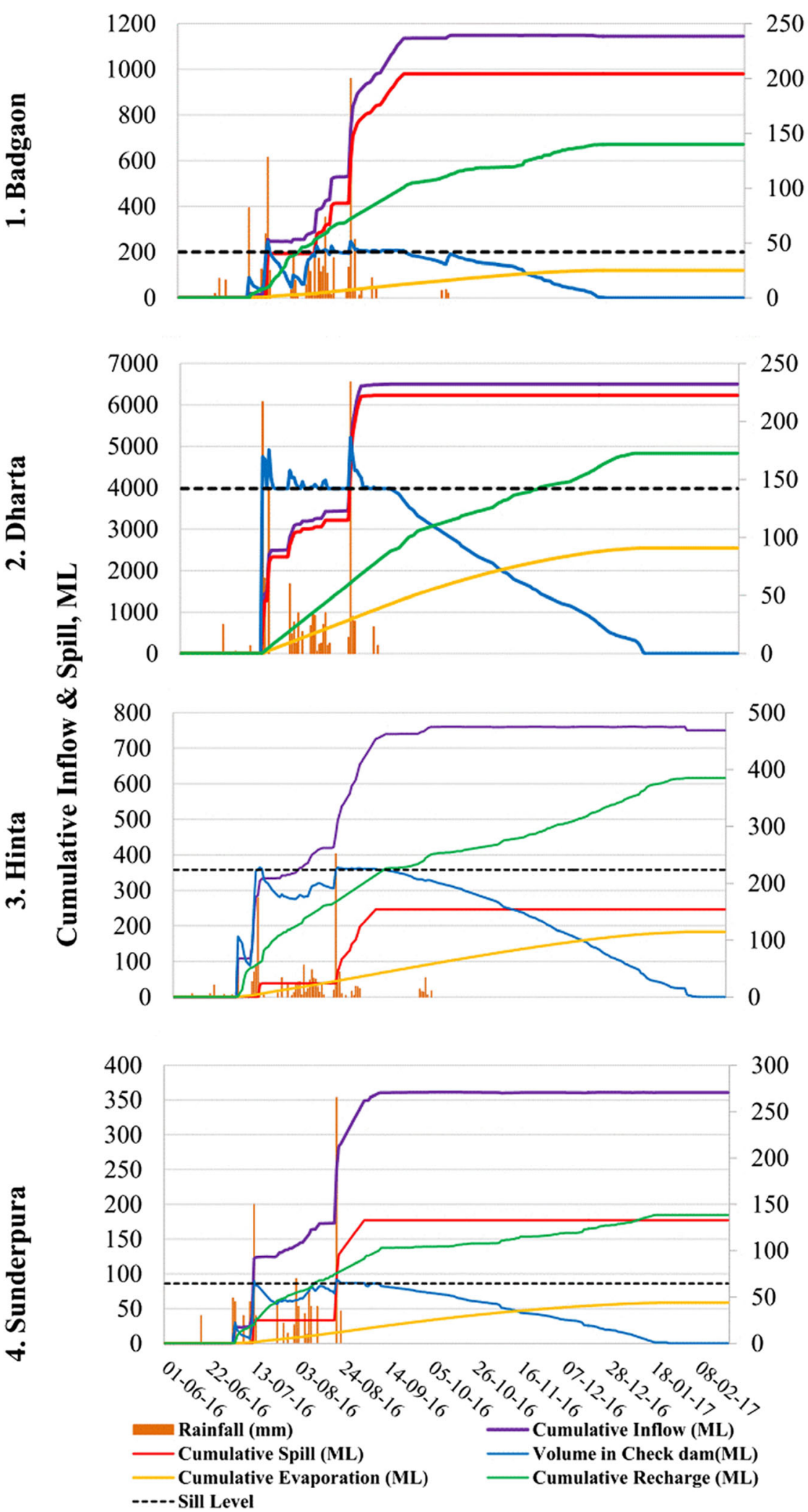

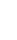

analysis of the whole catchment is also warranted to incorporate effects of reduced downstream flow including costs (e.g. risk of reduced agricultural production downstream) and benefits (reduced flood risk), such as have been evaluated by Chinnasamy et al. (2018b) for flood water harvesting in the Ramganga Basin, India. 
Table 2 Components of the annual water balance for four check dams (2014-2016). Means (bottom row) are given in italic

\begin{tabular}{lcrrrrrrr}
\hline Recharge structure & Year & Rainfall $(\mathrm{mm})$ & Inflow $\left(\mathrm{m}^{3}\right)$ & Recharge $\left(\mathrm{m}^{3}\right)$ & Spill $\left(\mathrm{m}^{3}\right)$ & Evaporation $\left(\mathrm{m}^{3}\right)$ & $\begin{array}{l}\text { Recharge/ } \\
\text { inflow }(\%)\end{array}$ & $\begin{array}{l}\text { Recharge/ } \\
\text { capacity }(-)\end{array}$ \\
\hline Badgaon & 2014 & 505 & 349,000 & 113,000 & 218,000 & 19,000 & $32 \%$ & 2.86 \\
& 2015 & 614 & 189,000 & 56,000 & 129,000 & 4,700 & $27 \%$ & 1.34 \\
& 2016 & 1,161 & $1,145,000$ & 143,000 & 980,000 & 26,000 & $12 \%$ & 3.40 \\
Dharta & 2014 & 535 & $1,312,000$ & 299,000 & 954,000 & 64,000 & $23 \%$ & 2.19 \\
& 2015 & 596 & 192,000 & 157,000 & 0 & 44,000 & $81 \%$ & 1.12 \\
Hinta & 2016 & 1,151 & $6,502,000$ & 180,000 & $6,228,000$ & 94,000 & $3 \%$ & 1.27 \\
& 2014 & 771 & 949,000 & 518,000 & 358,000 & 91,000 & $55 \%$ & 2.32 \\
Sunderpura & 2015 & 673 & 331,000 & 286,000 & 0 & 63,000 & $86 \%$ & 1.28 \\
& 2016 & 1,387 & 750,000 & 388,000 & 246,000 & 115,000 & $52 \%$ & 1.48 \\
Mean or total & 2014 & 485 & 54,000 & 46,000 & 0 & 8,000 & $85 \%$ & 0.71 \\
\hline
\end{tabular}

\section{Sensitivity analysis for water balance}

The sensitivity of water balance components to the estimated evaporation rate, the discharge coefficient of the weir and the estimated wet-weather-infiltration rate (WWIR) were calculated. Results for the Hinta check dam (the largest check dam studied) in 2014 (the "average" year) are shown in Table 3. Each parameter in turn was increased from its "base case" value by $20 \%$ and the corresponding percentage change in each of the water balance components was calculated. Increasing the rate of evaporation by $20 \%$ gives a directly proportional increase in the volume evaporated; however, the reduction in recharge is only $3.5 \%$ because the evaporation was only $18 \%$ of the recharge for the base case. Increasing the weir coefficient has a directly proportional impact on spill and increases the calculated inflow by $7.5 \%$ but has no effect on recharge as the recharge calculation does not make use of inflow or outflow. Increasing the WWIR by $20 \%$ increases the calculated recharge by only $2.4 \%$ and inflow by $1.2 \%$ with a very small decline in calculated evaporation. The main reason for low sensitivity of recharge to WWIR is that $87 \%$ of the "base case" recharge occurred in dry weather. The low sensitivity of calculated recharge to these parameters that are extrapolated to remote streambed structures, or estimated on the basis of daily gaugeboard readings by farmers, suggests that the method used is suitably robust for estimating recharge from check dams with this level of data availability.

Dashora et al. (2018) analysed the reliability of farmer measurements of check-dam water levels and found that $96 \%$ of readings were within $\pm 1 \mathrm{~cm}$ of values from concurrent photographs as read by a university researcher. In summary, while runoff estimates are considered unreliable, the recharge estimates were found to be relatively insensitive to unmeasured parameters and are considered robust.

\section{Runoff coefficient}

The check-dam inflow volume was calculated on a daily basis using water level measurements and area-volume elevation curves, to calculate inflow, spill, recharge and evaporation. No information on runoff coefficients (ROC) was available in these check dam catchments, so results were compared with estimates from Strange's table (source: Subramanya 2008), which is commonly used in India to estimate annual monsoon runoff without the ability to validate predictions. Knowing the low level of accuracy of the spill calculation based on only daily water level readings, this analysis was partitioned to focus on only the years and check dams with no spill, where inflow estimates were considered reliable. Rainfall was recorded only at a single rain gauge in or adjacent to each

Table 3 Sensitivity analysis of the water balance components at Hinta check dam 2014

\begin{tabular}{|c|c|c|c|c|c|c|c|}
\hline Parameter & Initial value & Adjusted value & Change from base case $(\Delta \%)$ & Recharge $(\Delta \%)$ & Inflow $(\Delta \%)$ & Spill $(\Delta \%)$ & Evaporation $(\Delta \%)$ \\
\hline Evaporation (mm/day) & 5 & 6 & 20 & -3.5 & 0 & 0 & 20 \\
\hline Weir coefficient $\left(C_{1}\right)$ & 1.6 & 1.92 & 20 & 0 & 7.5 & 20 & 0 \\
\hline $\mathrm{WWIR}^{\mathrm{a}}$ (mm/day) & 26 & 31 & 20 & 2.4 & 1.2 & 0 & -0.4 \\
\hline
\end{tabular}

${ }^{\mathrm{a}}$ The initial value of wet-weather-infiltration rate $(W W I R)$ is taken as the calculated mean dry-weather-infiltration rate (MDWIR) 
catchment that ranged up to 1,705 ha. The seasonal runoff coefficient was calculated using the seasonal inflow and dividing by the estimated volume of seasonal rainfall on the catchment. Table 4 shows that for the three cases occurring in the "dry" year, 2015, the best predictor occurred under Strange's "bad" (least runoff) catchment category, which still overestimated runoff by a factor 1.8-5.1. Runoff in the "average" year 2014 at Sunderpura compared very favourably with Strange's table predicted runoff for an "average" catchment type. This information suggests that Strange's table should be used with caution.

\section{Mean dry-weather infiltration rate (MDWIR)}

There are two main factors that dictate recharge from any check dam, the presence of water in the check dam and its rate of infiltration. The MDWIR, measured over days when water level is lower than the weir crest and falling at least as fast as the evaporation rate, is taken to be the rate of recharge during all other times, when inflows are estimated. The errors, some compensating, associated with this approximation are discussed by Dashora et al. (2018).

During this study, MDWIRs ranged between 10 and $57 \mathrm{~mm} /$ day, and the mean was $27 \mathrm{~mm} /$ day, more than 5 times the estimated evaporation rate from the dam surface of $5 \mathrm{~mm} /$ day (Table 5). Importantly, the highest DWIR was observed at Badgaon in 2015, immediately following manual scraping to remove silt from the floor of the check dam. The two lowest rates were recorded in Dharta and Hinta check dams immediately following mechanical scraping of the check dams, with the lowest rate after two successive years of mechanical desilting. MDWIR in the driest year 2015 is particularly clear where the largest increase from 2014 occurred in the handscraped check dam and the only decline was in the mechanically scraped check dam. This appears to be evidence of soil compaction by the heavy machinery used at Dharta check dam, which actually had the opposite of the intended effect of scraping.

From Table 5, it can be seen that MDWIR was highest in 2015, the 'dry' year, for all check dams except for mechanically scraped Dharta, and was lowest in 2016 the 'wet' year for all check dams. In 2014, the 'average' year, MDWIR had intermediate values close to the mean of the 3 years for each check dam. Although this is a small sample and influenced also by desilting, it appears that wetter seasons produce lower infiltration rates. One possible reason for this is that higher flow years produce higher rates of siltation; however, this would also suggest a monotonic decline in MDWIR, which did not occur in 2015, even though in three check dams there was no spill and hence no scour and flushing of sediment. Another factor could be differences in water temperature affecting kinematic viscosity of water, and hence hydraulic conductivity of streambed sediments and is discussed later.

A third consideration was the impact of wetter years resulting in higher natural recharge to the unconfined hardrock aquifer causing water table to rise and hydraulic connection with the impounded surface water. The process of hydraulic connection has been studied and modelled with a boundary element model having a moving upper surface and found to quickly reduce the recharge rate to about $10-20 \%$ of the preceding hydraulically disconnected rate, due to change in hydraulic gradient surrounding the streambed (Dillon and Liggett 1983) and the effect is larger for wider impoundments such as check dams (from electrical resistance analogue models, Bouwer 1978; and using a boundary element model, Dillon 1984). The differences in MDWIR between check dams in any year (except the first before any desilting) were similar to or larger than differences between years, suggesting that the effects of desilting, combined with other variations between sites, were as significant as variations between years (Fig. 4). The year of least standard deviation and coefficient of variation was 2014, before desilting commenced. The check dam with highest standard deviation across the three years, more than twice that of others, was Badgaon, the manually scraped check dam, suggesting that this change was significant.

The changes in MDWIR between 2014 and 2015 would be the changes least influenced by groundwater interactions. Relative to the net increase for unscraped check dams of $13 \%$, the Badgaon check dam that was scraped by hand labour increased a further $70 \%$. For the Dharta check dam that was scraped using heavy machinery, its MDWIR decreased $18 \%$ and so relative to the unscraped check dams declined by $31 \%$. Although this is a very small data set, the implications could

Table 4 Comparison of calculated seasonal runoff coefficient (ROC) based on water balance and estimated from Strange's table

\begin{tabular}{lllllll}
\hline Recharge structure & Year & Rainfall (mm) & ROC measured (-) & ROC (Strange's table) (-) & $\begin{array}{l}\text { Ratio Strange's/ } \\
\text { measured }(-)\end{array}$ & $\begin{array}{l}\text { Best fit Strange's } \\
\text { catchment type }\end{array}$ \\
\hline Dharta & 2015 & 596 & 0.019 & 0.097 & 5.1 & 1.9 \\
Hinta & 2015 & 673 & 0.058 & 0.109 & 1.0 \\
Sunderpura & 2014 & 485 & 0.102 & 0.104 & 1.8 & "Bad" \\
& 2015 & 406 & 0.029 & 0.052 & "Average" \\
\hline
\end{tabular}


Table 5 Mean dry weather infiltration rates $(M D W I R)$ during the study period 2014-2016 for four check dams in relation to desilting. Means are given in italic

\begin{tabular}{|c|c|c|c|c|c|c|}
\hline \multirow[t]{2}{*}{ Recharge structure } & \multicolumn{3}{|c|}{ MDWIR (m/day) } & \multirow{2}{*}{$\begin{array}{l}\text { Mean DWIR } \\
(\mathrm{m} / \text { day) } \\
2014-2016\end{array}$} & \multirow{2}{*}{$\begin{array}{l}\text { SD DWIR (m/day) } \\
\text { 2014-2016 }\end{array}$} & \multirow{2}{*}{$\begin{array}{l}\mathrm{CoV}(-) \\
2014-2016\end{array}$} \\
\hline & 2014 & 2015 & 2016 & & & \\
\hline Badgaon & 0.031 & $0.057^{\mathrm{a}}$ & 0.029 & 0.039 & 0.016 & 0.401 \\
\hline Dharta & 0.022 & $0.018^{\mathrm{b}}$ & $0.010^{\mathrm{b}}$ & 0.017 & 0.006 & 0.359 \\
\hline Hinta & 0.026 & 0.026 & $0.018^{\mathrm{b}}$ & 0.023 & 0.005 & 0.201 \\
\hline Sunderpura & 0.028 & 0.035 & 0.019 & 0.027 & 0.008 & 0.297 \\
\hline Mean & 0.027 & 0.034 & 0.019 & 0.027 & 0.008 & 0.278 \\
\hline SD & 0.004 & 0.017 & 0.008 & 0.009 & - & - \\
\hline $\mathrm{CoV}$ & 0.140 & 0.495 & 0.410 & 0.344 & - & - \\
\hline
\end{tabular}

$S D$ standard deviation; $D W I R$ dry weather infiltration rate; $C o V$ coefficient of variation ( $\mathrm{SD} /$ mean)

${ }^{\text {a }}$ Following manual scraping of silt

${ }^{\mathrm{b}}$ Following mechanical scraping of silt be very important information for the design of future maintenance programs for check dam desilting. Check dams for desilting could be prioritized on the basis of measured MDWIR. This occurred in 2016 when the two check dams with lowest MDWIR in 2015 were scraped. Unfortunately, this was by mechanical scraping and MDWIR decreased in both cases, but decreases were recorded at all check dams. More data will be needed to help formulate appropriate strategies, accounting for the benefits and costs of desilting, with a greater emphasis on methods that avoid compaction of sediments. Elsewhere, it has been shown that scraping has improved recharge capacity. In a study by Mousavi and Rezai (1999) of three artificial recharge sites in Isfahan Province, central Iran, on average, the average infiltration capacity of the untreated recharge facilities had declined to $20.3 \%$ of its initial value, and that $68.3 \%$ of initial infiltration capacity was restored after scraping off the top $15 \mathrm{~cm}$ of silt.

\section{Factors affecting dry weather infiltration rate (DWIR)}

Variations in DWIR are shown over the 3 years and four sites in Fig. 5. Each site and year follows a pattern of high rates early in each monsoon season, reaching $150 \mathrm{~mm} /$ day at each site for short periods. This reduces to low values in the midmonsoon period and in prolonged monsoons, most notably in 2016, when there are extended periods of very low infiltration rates. Finally, as the season ends, the rate of infiltration increases at most check dams.

Although the air temperature ranges from 15 to $30^{\circ} \mathrm{C}$ during the ponding period, there was no correlation found between DWIR and air temperature. Air temperature falls at the end of each monsoon season when infiltration rates increase; hence, daily air temperature was not responsible for the observed increase in infiltration rates. As water level rises within a check dam it had been expected that this would increase the hydraulic gradient for seepage; however, this is not supported by the observations. These show lower DWIRs at higher storage levels, but due to the larger surface area, daily volumes of recharge are less affected.

Groundwater levels were monitored daily at three wells closest to each check dam when they contained water and weekly throughout the rest of the year. At Badgaon the closest well was $68 \mathrm{~m}$ upstream of the weir. For other sites, the closest
Fig. 4 Mean dry-weather infiltration rates for each year and each check dam

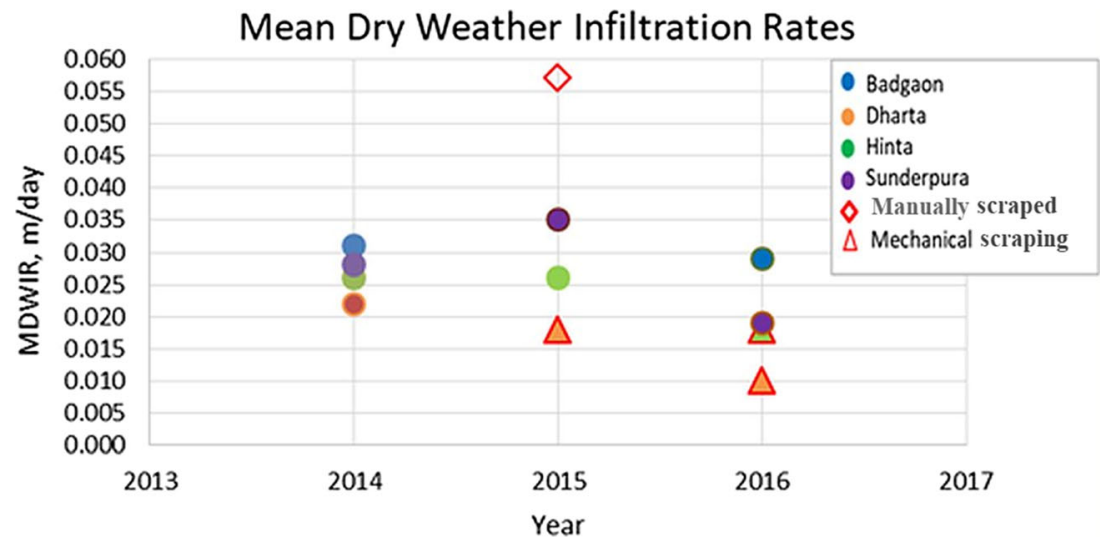


Fig. 5 Dry-weather-infiltration rates for four check dams with respect to time

\section{DWIR vs Time}

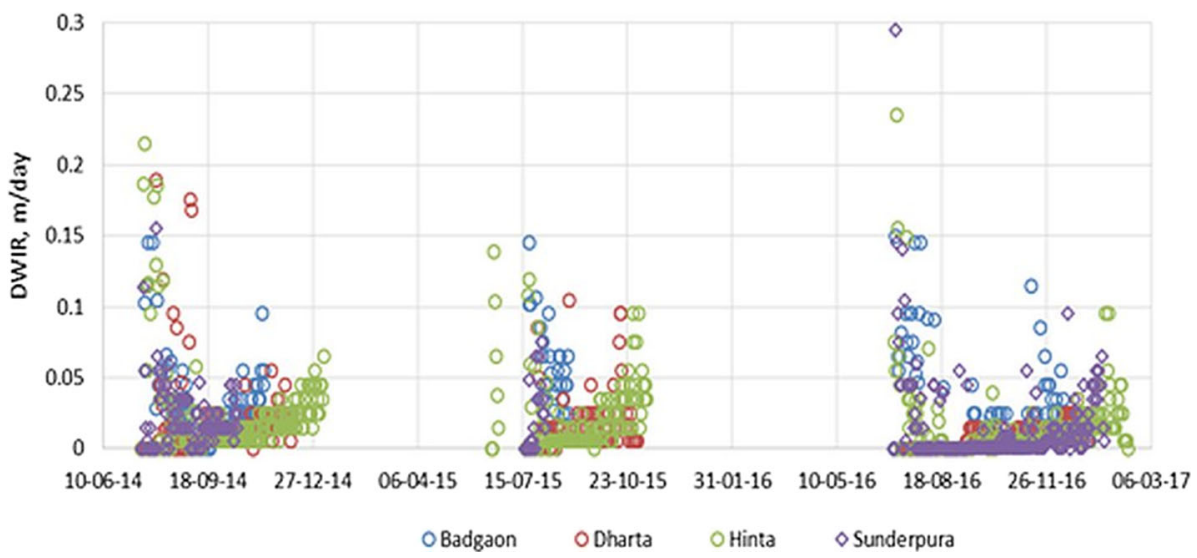

\section{Badgaon 2014-16}

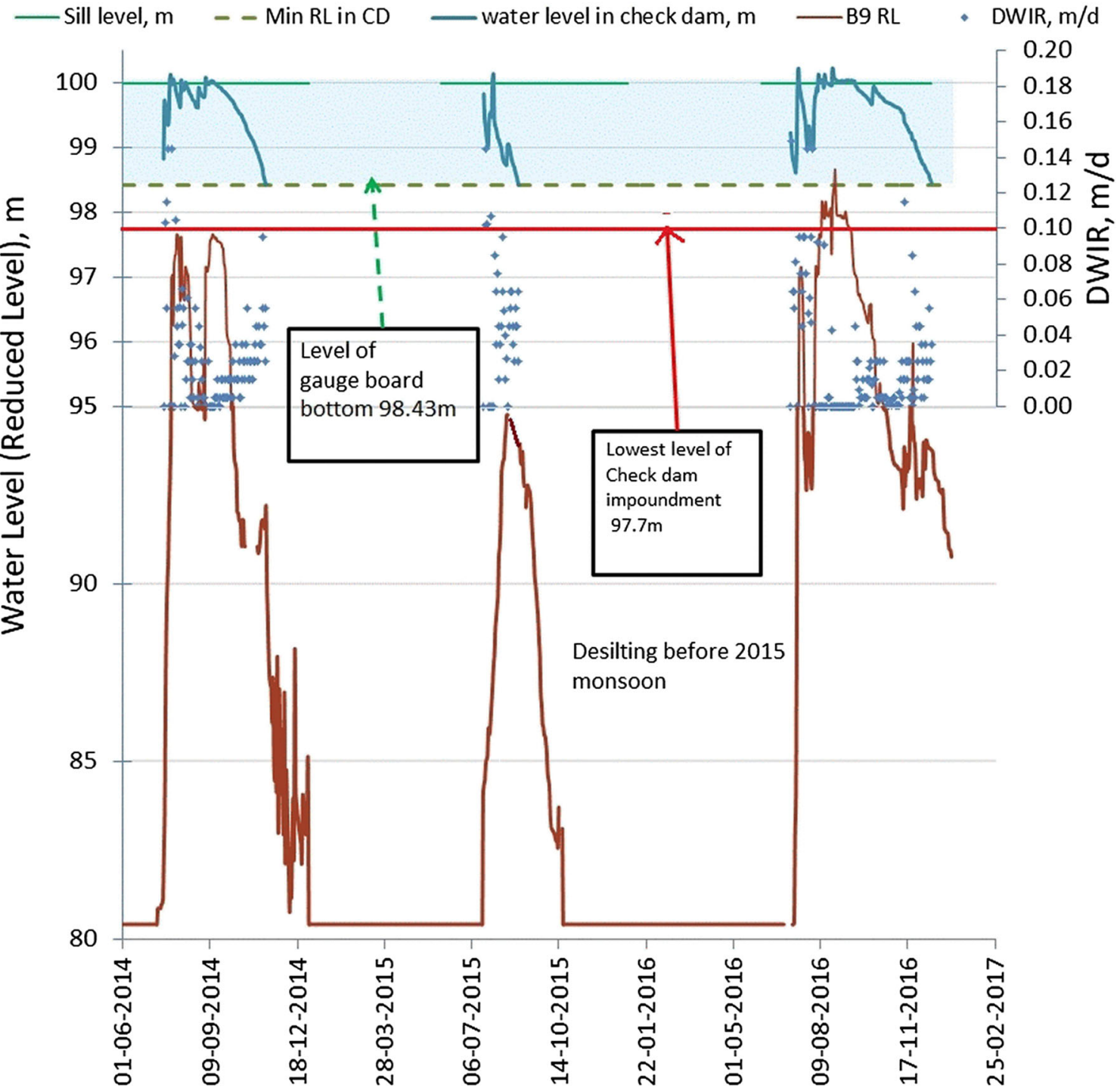

Fig. 6 Water level in Badgaon check dam and nearby well (B9) with daily DWIR (2014-2016) 
well was $>470 \mathrm{~m}$ from the check dam. Figure 6 compares daily values for the groundwater in the proximal well and the Badgaon check dam water level. The term 'reduced level' (RL) is used as the cease to flow (spillway crest) level of the horizontal broad crested weir is adopted as a temporary bench mark and assigned a reduced level of $100 \mathrm{~m}$ (RL $100 \mathrm{~m}$ ). The lowest elevation of the impoundment is at RL $97.7 \mathrm{~m}$. The DWIR is plotted daily using a secondary axis (on the right).

The bottom of well B9 is at RL $80 \mathrm{~m}$, and each year in the dry season the well ran dry. In the wet seasons of
2014, 2015 and 2016, the peak groundwater level reached RL $97.7 \mathrm{~m}$ (the lowest ground surface), 95 , and $98.7 \mathrm{~m}$ respectively. The DWIR reduces to approximately zero whenever the groundwater elevation at B9 is above RL $97 \mathrm{~m}$, which corresponds with hydraulic connection between the aquifer and the check dam. This is most clearly observed in 2016. At this location, surface-water levels remained above groundwater level so no direct groundwater discharge to the check dam occurred; however, observation of Fig. 3 shows a sustained period of spill between
Fig. 7 Water level in Sunderpura check dam and nearby well (SP26) with daily DWIR (2014 2016)

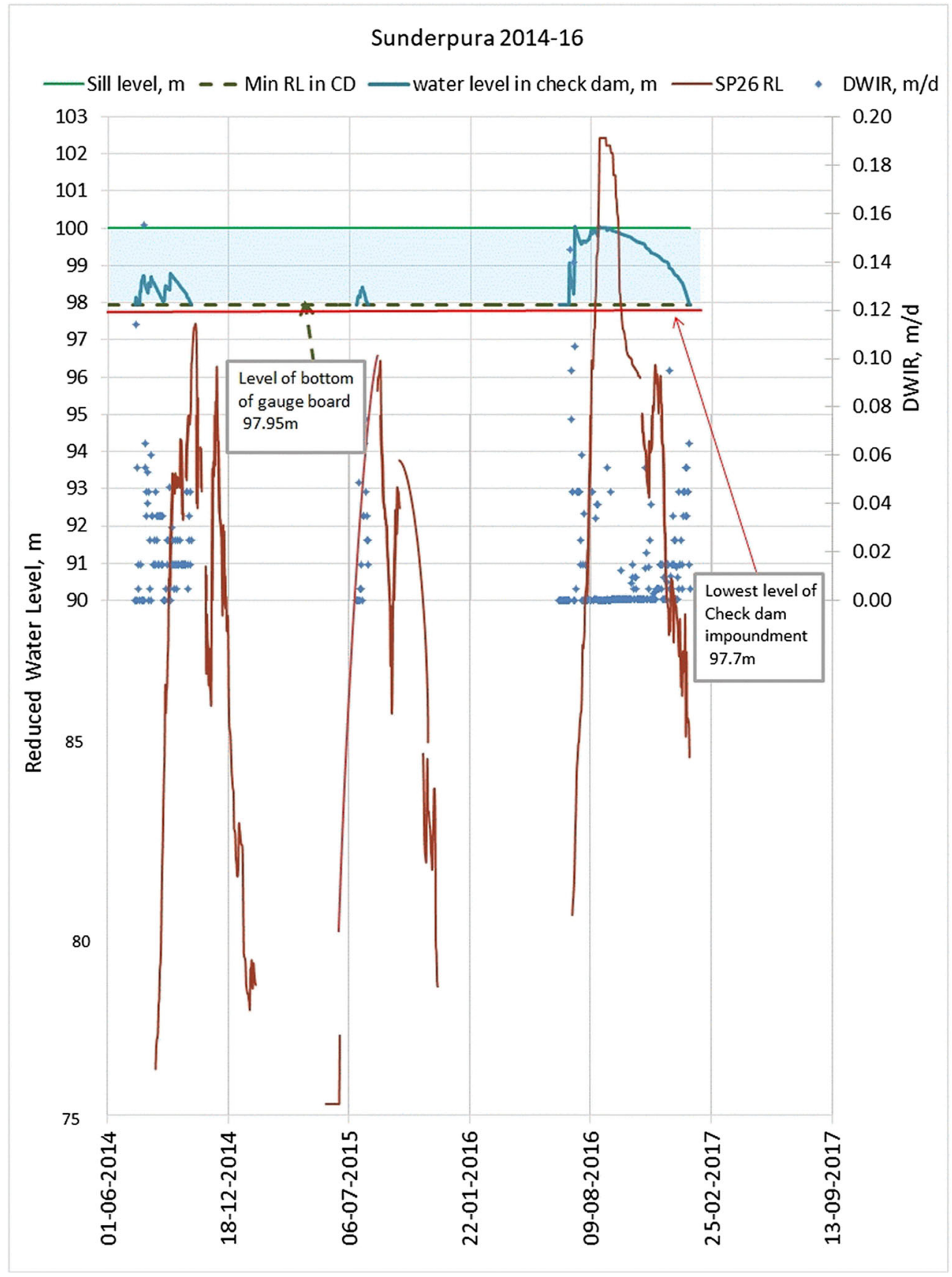


24 August and 14 September 2016 with only intermittent rainfall, suggesting that groundwater discharge was occurring into the stream upstream of the check dam.

Similar data are shown in Fig. 7 for Sunderpura check dam, where the closest observation well (SP26) is $656 \mathrm{~m}$ downstream of the check dam, and the local temporary benchmark for the crest of the check dam is taken to be $100 \mathrm{~m}$ and the lowest ground surface of the impoundment is $97.7 \mathrm{~m}$. In the wet seasons of 2014, 2015 and 2016 the peak groundwater level reached 97.4, 96.4, and more than $100.5 \mathrm{~m}$ respectively. In years 2014 and 2015 there was no spill and marginal evidence of hydraulic connection in 2014; however, in 2016, the wet year, the groundwater level in SP26 not only demonstrated hydraulic connection but rose to above the level of surface water in the check dam due to significant natural recharge. This suggests that groundwater discharge to the check dam occurred between 24 August and 7 September as also indicated by spill in Fig. 3. When groundwater levels in well SP26 dropped below about $96.5 \mathrm{~m}$ the DWIR again increased, suggesting that the check dam and aquifer had again become hydraulically disconnected.

At Dharta and Hinta check dams, the monitored wells were not sufficiently close to the check dams to conclusively determine whether hydraulic connection occurred in 2014. Hydraulic connection was unlikely in 2015 when levels peaked 5-10 m below the lowest levels of the impoundments, but was evident from a period of low DWIR, and from evidence of continuous flow from 24 August to 4 Sept 2016 for Dharta and from 24 August to 10 Sept 2016 for Hinta. Thus, each check dam, depending on its position in the catchment, the nature of the aquifer and ambient groundwater depth, had different propensities for hydraulic connection, which suggests that for longterm studies there would be a great advantage in having monitoring wells very close to check dams to interpret recharge behaviour.

\section{Benefit cost analysis}

\section{Capital and maintenance costs}

The cost of each check dam was taken from government department records and varied from 150,000 to 500,000 Indian Rupees (INR) in their year of construction, which ranged from 1995 to 2005 (Table 6). The benefit cost evaluation here is done in Indian Rupees (INR) in the year 2014. In that year the average exchange rate with the US dollar was 60 INR per US\$ (max 63.69, $\min 58.43$ ).

The maintenance costs of each check dam (primarily scraping for silt removal and occasional repairs to concrete structures) were estimated for manual and mechanical scraping (Table 7). No maintenance costs were recorded for the four check dams from their establishment until after 2014, and for Sunderpura check dam there has been no maintenance for 22 years. The check dams had quite different mean annual maintenance costs, which discounted to year 2014 INR, ranged from 0 to $7.3 \% /$ year of the capital costs with a mean of $2.9 \%$ year.

Table 8 summarizes the annualized costs expressed in terms of the present value in 2014 INR, for capital, and applied to all check dams with the assumed maintenance cost, taken as the mean from Table 7. It also shows the average annual recharge over the 3 years of record, 2014-2016. Using the approximation that the mean annual recharge in these 3 years represents the mean annual recharge over a 30 year life of these check dams, given this level of maintenance, the average unit cost of annual recharge (CR) is obtained (Eq. 5).

\section{Benefits}

Benefits were calculated using data provided by the Irrigation Depatment, Rajasthan Department of Agriculture (2017) and ICAR (2009) and Eqs. (6)-(9). Major rabi season crops are

Table 6 Capital costs and dimensions of check dams and present value of capital costs in 2014 (primary data supplied by Rajasthan Watershed Department and Irrigation Department)

\begin{tabular}{lllllllll}
\hline $\begin{array}{l}\text { Recharge } \\
\text { structure }\end{array}$ & $\begin{array}{l}\text { Year } \\
\text { built }\end{array}$ & $\begin{array}{l}\text { Capacity } \\
\left(\mathrm{m}^{3}\right)\end{array}$ & $\begin{array}{l}\text { Crest length } \\
(\mathrm{m})\end{array}$ & $\begin{array}{l}\text { Crest height } \\
(\mathrm{m})\end{array}$ & $\begin{array}{l}\text { Capital cost } \\
(\mathrm{INR})^{\mathrm{a}}\end{array}$ & $\begin{array}{l}\text { PVC (INR) } \\
(2014)\end{array}$ & $\begin{array}{l}\text { AC (INR) } \\
(2014)\end{array}$ & $\begin{array}{l}\text { PVC } / \mathrm{m}^{3} \text { capacity } \\
\left(\mathrm{INR} / \mathrm{m}^{3} \text { cap) }(2014)\right.\end{array}$ \\
\hline Badgaon & 2001 & 42,000 & 12.7 & 1.57 & 150,000 & 407,900 & 36,200 & 9.7 \\
Dharta & 2005 & 140,000 & 66.0 & 1.82 & 500,000 & 999,500 & 88,800 & 7.1 \\
Hinta & 2000 & 223,000 & 45.1 & 2.62 & 450,000 & $1,321,700$ & 117,000 & 5.9 \\
Sunderpura & 1995 & 64,400 & 30.0 & 2.05 & 225,000 & 971,000 & 86,200 & 15.1 \\
Total & - & 469,400 & - & - & - & $3,700,000$ & 328,200 & 7.9 \\
\hline
\end{tabular}

${ }^{\text {a }}$ Capital cost in the year of construction

${ }^{\mathrm{b}} P V C$ is the present value of capital cost inflated to year 2014 using Eq. (1) with a discount rate of $8 \%$

${ }^{\mathrm{c}} A C$ is the annualized present value of capital cost in 2014 as calculated by Eq. (2) 
Table 7 Record of maintenance of each check dam, showing year, method and cost for each check dam (primary data supplied by Watershed Department, Block Bhindar, Rajasthan)

\begin{tabular}{|c|c|c|c|c|c|c|}
\hline $\begin{array}{l}\text { Recharge } \\
\text { structure }\end{array}$ & $\begin{array}{l}\text { Year of } \\
\text { maintenance }\end{array}$ & Method of scraping and work done & $\begin{array}{l}\text { Volume } \\
\text { removed }\left(\mathrm{m}^{3}\right)\end{array}$ & $\begin{array}{l}\text { Cost } \\
\text { (INR) }\end{array}$ & $\begin{array}{l}\text { PV maintenance costs } \\
\left(\text { INR) }(2014)^{\mathrm{a}}\right.\end{array}$ & $\begin{array}{l}\text { AM (Avg. annual } \\
\text { maintenance cost) } \\
(\mathrm{INR})(2014)^{\mathrm{b}}\end{array}$ \\
\hline Badgaon & 2015 & Manual desilting & 2,408 & 150,000 & 139,000 & 10,700 \\
\hline Dharta & $\begin{array}{l}2015 \\
2016\end{array}$ & $\begin{array}{l}\text { Mechanical desilting } \\
\text { Mechanical desilting and repair side } \\
\text { walls of weir }\end{array}$ & $\begin{array}{l}2,981 \\
2,676\end{array}$ & $\begin{array}{l}184,500 \\
400,000\end{array}$ & $\begin{array}{l}171,000 \\
343,000\end{array}$ & 73,400 \\
\hline Hinta & 2016 & $\begin{array}{l}\text { Mechanical desilting and repair side } \\
\text { walls of weir }\end{array}$ & 936 & 400,000 & 343,000 & 24,500 \\
\hline Sunderpura & None & None & 0 & 0 & 0 & 0 \\
\hline Total & - & - & 9,000 & $1,134,500$ & 995,600 & 108,600 \\
\hline Mean & - & - & 2,250 & 284,000 & 248,900 & $27,144^{\mathrm{c}}$ \\
\hline
\end{tabular}

${ }^{\text {a }}$ Present value of maintenance cost inflated to year 2014 as per Eq. (3) with a discount rate of $8 \%$

${ }^{\mathrm{b}} A M$ is the annualized maintenance cost calculated from Eq. (3)

${ }^{\mathrm{c}}$ MAM mean annualised maintenance cost per recharge structure

wheat and mustard having on average 44 and $36 \%$ of the total cropped area, respectively. Water uses for these two dominant crops were measured in farmers' fields by installing a water meter near the well head. For the remaining mix of crops, the water use was referred from sources as listed in the footnote of Table 9 . The area fraction of opium $(0.7 \%)$ is very small compared to major crops in Dharta watershed, but to eliminate any possible impression that this crop may be responsible for elevating the determined benefit cost ratios, the net profit and water use of wheat were substituted for opium. This marginally reduced the area-weighted profit per unit volume of water from 2.42 to $2.36 \mathrm{INR} / \mathrm{m}^{3}$ (in INR 2014) for Dharta watershed using groundwater. This lower value was used in the benefit:cost analysis.

This paper has addressed only one aspect of the benefits of recharge enhancement, being the main motivation to secure and expand rabi season irrigation supplies. Beernaerts (2006) proposed an evaluation framework for groundwater recharge enhancement systems for improved irrigated agriculture with economic, social and environmental indicators. In addition to the economic evaluation of the current study, Beernaerts (2006) proposed evaluating: economic impacts on improved soil fertility using silt removed from check dams; the potential for increase or decrease in fluoride or arsenic concentration in the aquifer and for pollution by faecal pathogens, taking account of water quality improvements (e.g., as reported by Patel 2002 with localized lowering of salinity); the rise in water table with consequent reduction in energy required for pumping, improved conditions for survival of riparian trees and control of saline intrusion in coastal areas; the current externalities faced by downstream communities of reduced water availability for irrigation or city water supply dams and reduced incidences and severity of flooding and erosion. Beernaerts (2006) also considered a range of financial indicators for evaluating economic impacts of recharge enhancement and suggested that those measures that brought supply side and demand-side (such as water use

Table 8 Discounted annualized present value costs (INR 2014) for capital and maintenance for each check dam, average annual recharge for 2014 2016, and the resultant unit cost of recharge for each of the four check dams

\begin{tabular}{lccccc}
\hline Recharge structure & $\mathrm{AC}$ (INR/year) & $\mathrm{MAM}^{\mathrm{b}}(\mathrm{INR} /$ year) & $\mathrm{ACM}^{\mathrm{c}}$ (INR/year) & $\begin{array}{l}\text { Ave annual recharge } \\
2014-2016\left(\mathrm{~m}^{3} / \text { year) }\right.\end{array}$ & $\mathrm{CR}^{\mathrm{d}}\left(\mathrm{INR} / \mathrm{m}^{3}\right)$ \\
\hline Badgaon & 36,200 & 27,144 & 63,344 & 104,000 & 0.61 \\
Dharta & 88,800 & 27,144 & 115,944 & 212,000 & 0.55 \\
Hinta & 117,000 & 27,144 & 144,144 & 397,333 & 0.36 \\
Sunderpura & 86,200 & 27,144 & 113,344 & 65,333 & 1.73 \\
Total & 328,200 & 108,575 & 436,775 & 778,667 & 0.56 \\
\hline
\end{tabular}

${ }^{\mathrm{a}} A C$ is annualized capital costs in INR (2014) (from Eq. 2 and Table 6)

${ }^{\mathrm{b}}$ MAM is mean annualized maintenance costs in INR (2014) (from Eq. 3 and Table 7)

${ }^{\mathrm{c}} A C M$ is annualized cost that covers capital and maintenance in INR (2014) (from Eq. 4)

${ }^{\mathrm{d}}$ Average unit cost of annual recharge from check dams (from Eq. 5) 


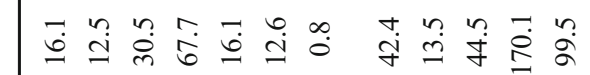

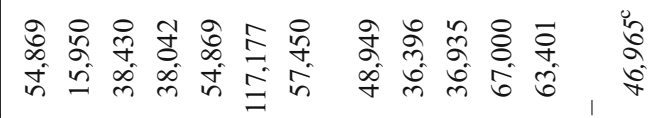

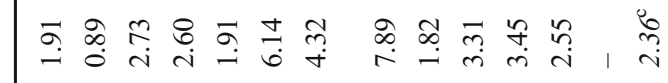

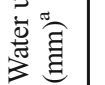

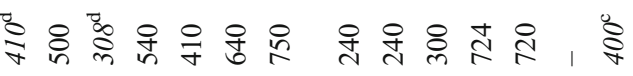

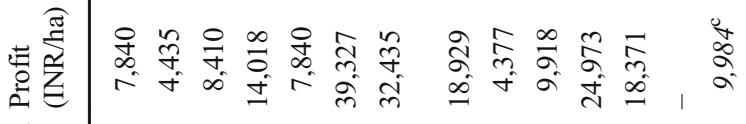

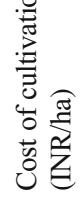

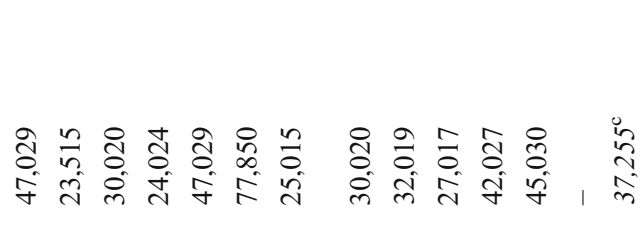

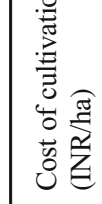

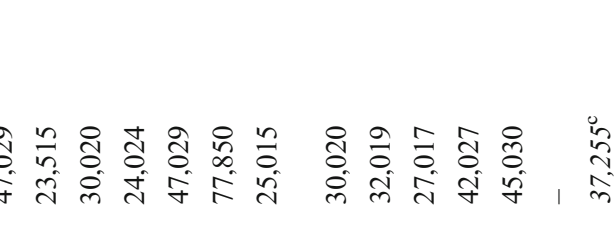

$\geq \overrightarrow{0}$

害

㲾

要

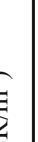

焉

京

굴

递 <

$\stackrel{1}{\overrightarrow{5}}$

ㄱ.

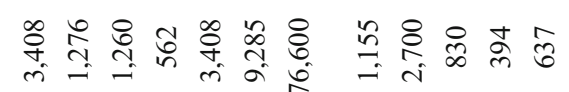

苞.

安递

等 ๘ँ

등 ڤ

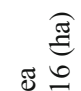

(1)

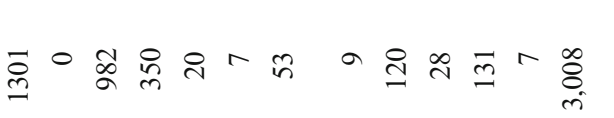

हृ

造瓷 \&ু

氖

\&̊ำ

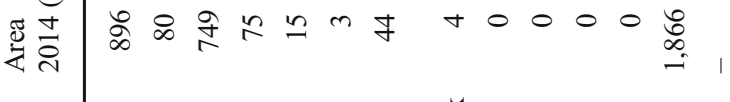

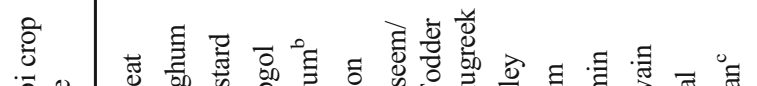

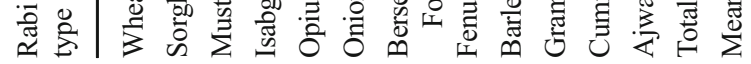

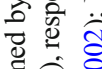

घิ宀 웡

产离

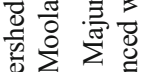

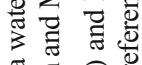

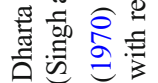

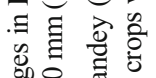

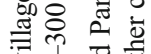

워

言密

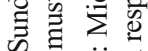

密葶

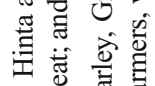

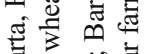

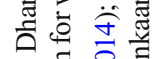

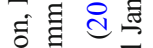

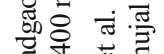

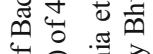

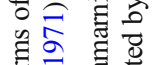

帚 㱏

퍼 등

造 岂

远

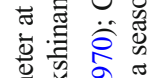

ํํㅇ

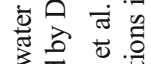

焉 
Table 10 Benefits and costs and benefit:cost ratio attributable to recharge from four check dams

\begin{tabular}{|c|c|c|c|c|c|}
\hline Recharge structure & $\begin{array}{l}\text { Avg. annual recharge } \\
2014-2016\left(\mathrm{~m}^{3} / \text { year }\right)\end{array}$ & $\mathrm{CR}^{\mathrm{a}}\left(\mathrm{INR} / \mathrm{m}^{3}\right)$ & $\mathrm{BR}^{\mathrm{b}}\left(\mathrm{INR} / \mathrm{m}^{3}\right)$ & $\operatorname{BCR}^{\mathrm{c}}(-)$ & $\begin{array}{l}\text { Net Benefits of check } \\
\text { dam recharge (INR/year) }\end{array}$ \\
\hline Badgaon & 104,000 & 0.61 & 2.36 & 3.9 & 178,000 \\
\hline Dharta & 212,000 & 0.55 & 2.36 & 4.3 & 375,000 \\
\hline Hinta & 397,333 & 0.36 & 2.36 & 6.6 & 779,000 \\
\hline Sunderpura & 65,333 & 1.73 & 2.36 & 1.4 & 39,000 \\
\hline Total & 778,667 & - & - & - & $1,371,000$ \\
\hline Mean & - & 0.56 & 2.36 & 4.1 & - \\
\hline
\end{tabular}

${ }^{\text {a }} C R$ : average unit cost of annual recharge from check dams calculated from Eq. (5)

${ }^{\mathrm{b}} B R$ : average unit benefit of annual recharge calculated from Eq. (8)

${ }^{\mathrm{c}} B C R$ : average benefit cost ratio calculated from Eq. (9)

efficiency) into perspective would have advantage to communities for decision making on water management.

Gale et al. (2006) reported the results of a project to determine impacts of recharge structures on livelihoods in village communities. Their study showed the reasons why this is difficult. They found that a lack of baseline data on the 'before' recharge situation hampered longitudinal comparisons of 'before' and 'after' income. MAR typically forms one of a number of watershed activities and agricultural reforms aimed at improving resource productivity, generating employment and supporting livelihoods. Hence it would generally not be straight forward to isolate the effects of recharge structures from the other effects. Gale et al. (2006) proposed that comparisons between 'with' and 'without' recharge structures also require a control group with a similar environmental and socio-economic profile to the 'with' group. This would enable confounding effects of rainfall variations between years and other factors affecting productivity to be removed. Finally, changes in economic conditions, access to infrastructure and other external factors may also impact on agricultural production. Gale et al. (2006) concluded that "attributing changes in livelihood strategies and outcomes to watershed development, and to MAR specifically, is therefore difficult to do with confidence". However, surveys of farmers for their records and perceptions did reveal an association between increased livelihoods and streambed recharge structures. The approach used in this current study using recharge volumes from check dams determined from daily water balances, assuming a proportion of this (here 100\%) contributes to crop production, and using crop area weighted mix of net profit per cubic meter to value the benefit, is a more rational approach than the 'before and after' method, but is not without limitations, as discussed earlier.

A comparable analysis for agricultural value of water use using surface-water irrigation was undertaken by Garg et al. (2012) in the Upper Bhima sub-basin of Maharashtra. The gross income was calculated using crop yields and support prices of crops for 2003-2004 for a known volume of dam water released and cropped area. Then deducting the cost of cultivation gave net income and water productivity was calculated to range between US $\$ 0.02 / \mathrm{m}^{3}$ and US $\$ 0.03 / \mathrm{m}^{3}$. Other researchers, Hussain et al. (2007), compiled more recent estimates of the average value of agricultural water in several countries that varied among countries. For Indian irrigated areas, the average value of agricultural water use was estimated as US $\$ 0.09 / \mathrm{m}^{3}$. After accounting for inflation, the higher value of water benefits obtained for the current study (Table 9) is attributed to higher efficiency in the use of groundwater over surface water, as has been observed by Burke and Moench (2000).

\section{Benefit cost ratio (BCR)}

Benefit cost analysis is presented for the four studied check dams of Dharta watershed in Table 10. The unit cost of recharge, CR (Eq. 5), varies from 0.36 to $1.73 \mathrm{INR} / \mathrm{m}^{3}$ (from Table 8). The unit benefit of recharge, BR (Eq. 8), was found to be $2.36 \mathrm{INR} / \mathrm{m}^{3}$ (from Table 9) and is assumed constant for all check dams in this area. These unit values attributable to benefits and costs were used to calculate benefit:cost ratio (BCR) which ranged from 1.3 at Sunderpura check dam to 6.4 at Hinta check dam with a mean of 4.1 (Table 10). The Hinta check dam had the highest recharge (about half of the aggregate recharge of the four check dams), the lowest unit costs of recharge, and contributed $57 \%$ of aggregate net benefits from all four check dams. This suggests that the siting and design features were well matched for this check dam.

The earliest BCR found for Indian streambed recharge structures was for Baramati Taluka of Pune District, Maharashtra, which was declared in 1963 to be an area of "precarious scarcity" with total or near total crop failure occurring in 1 year in 3, due to drought. In response, a combined effort of government and NGOs constructed the first percolation tank in 1968, and by the end of 1978 more than 149 had been built with a combined capacity of $15 \mathrm{Mm}^{3}$ (Dillon 1983). Percolation tanks are similar to check dams except that they 
have an earthen embankment and a separate concrete spillway, rather than just a weir on a stream. At 1980 the feasibility criterion for construction of percolation tanks was for cost to be less than $1.9 \mathrm{INR} / \mathrm{m}^{3}$ detention capacity and the average value was $0.92 \mathrm{INR} / \mathrm{m}^{3}$ capacity (Dillon 1983). (In the current study this was $7.9 \mathrm{INR} / \mathrm{m}^{3}$ in 2014 Indian Rupees, approximately, half the cost from 1978 inflated at $8 \%$ pa rate to 14.7 $\mathrm{INR} / \mathrm{m}^{3}$.) There were no measurements to enable recharge to be estimated, although Dillon (1983) recommended installation of gaugeboards and monitoring water levels in streambed structures and wells. The current study demonstrates the value of having such data.

Based on Maharashtra Irrigation Department records, the mean capacity of these first 149 percolation tanks was $98,700 \mathrm{~m}^{3}$, and the average area benefitted by each tank was estimated to be 36.2 ha. The crop mix in this area was jowar (millet) (45\%), wheat (30\%), sugar cane (10\%), and vegetables, onions and gram (each 5\%). The Irrigation Department's estimated average annual increase in income per tank was 56,000 INR and net costs of production were not reported. The capacity of a tank divided by the estimated benefitted area is $272 \mathrm{~mm}$. This is not inconsistent with water use results for the current study considering crop types and the likelihood of annual recharge to exceed detention capacity. The resulting benefit:cost ratio (BCR) derived by Dillon (1983) based on a discount rate of $10 \%$ was $>6$. Using a 30 -year life and $8 \%$ discount rate, as per the current study, BCR would have been 7.0; however, for comparison with current data from Rajasthan (where profit is $28 \%$ of the increase in income), and allowing 3\% capital costs for annual maintenance, and a 30 -year life and $8 \%$ discount rate, a BCR of 1.5 is achieved. In the Baramati area the Irrigation Department also estimated a silt loading to percolation tanks of $1.7 \mathrm{~m}^{3} /$ year/ha of catchment area. It would be very informative to record the current status, maintenance history and also the DWIR on these percolation tanks $40-50$ years since construction.

The CGWB (2000) Guide on Artificial Recharge to Ground Water gives a brief summary of the procedure for undertaking an analysis to determine the benefit:cost ratio (BCR) of a recharge project, and gives the computed BCR for a number of recharge structures in Amravati District, Maharashtra. For three percolation tanks, BCR is 1.3-2.0, increasing with impoundment size (from 49,000 to $132,000 \mathrm{~m}^{3}$ ), and with an aggregate mean BCR of 1.76 . Cement plugs are smaller, with a typical detention volume of $4,000-10,000 \mathrm{~m}^{3}$, and for ten such structures the estimated BCR ranged from 0.88 to 5.80 with a mean of 1.88 . The method of recharge benefit calculation assumed that the difference in recharge, and hence area that can be irrigated resulting in increased crop income, is attributable entirely to the check dam. However, in the current study there are significant variations in recharge and crop production between years due to the amount and pattern of rainfall within the monsoon.
This and other agronomic factors would confound estimates of benefits attributable to check dams. A series of years before and after check dam construction would need to be compared to give confidence to these benefit estimates. Another advantage of the method used in this paper is that it can be applied even in the absence of information before the check dam was constructed. As presented in Table 9 for the area-weighted crop mix, the benefits can be calculated from per unit volume of recharged water even in a study period of 3 years. The benefit calculation depends on average crop mix in an area; thus, it can be applied for any check dam within the catchment.

Machiwal et al. (2004) used the contrast between expected production before and after check dam construction for a hypothetical example consistent with the authors' perceptions, to estimate benefits of small-waterharvesting structures suitable for catchments smaller than 30 ha in southern Rajasthan. Their analysis used a lifetime of 10 years and a $10 \%$ discount rate; the analysis took into account capital costs based on design of the structure and presumed an annual maintenance cost of $10 \%$ of capital costs for masonry structures and 25\%/year for earthen structures. The net profits per ha of wheat and mustard crops were slightly higher than those used in this current study after taking into account inflation. Importantly, they also considered benefits to occur during the kharif season, with one third of the benefits attributed to extra cropping in the kharif in their lower rainfall $(541 \mathrm{~mm})$ study area. In the current study, it was not possible to quantify benefits attributable to check dams of "life-saving" irrigation during dry spells in the monsoon. These benefits were ignored on the conservative presumption that the residual groundwater available for rabi irrigation may be reduced by irrigation in the kharif. Hypothetical benefit:cost ratios calculated by Machiwal et al. (2004) ranged from 5 for earthen structures to 3.5 and 1.9 for dry stone masonry of simple and more complex design, respectively. They concluded that concrete weirs, which cost considerably more, were not cost-effective in catchments of less than 30 ha.

By 2007 the Central Ground Water Board had revised and expanded its Manual on Artificial Recharge of Ground Water (CGWB 2007). In this, a chapter is devoted to economic evaluation of recharge schemes. The volume of recharge is estimated from the product of seepage rate, average area of water spread and the duration of storage. This implies monitoring of water levels in the check dam; however, the degree of adherence to this is unknown. Benefits can include income from additional agricultural production, and savings in pumping energy, as well as savings from constructing new tube wells and installing new pumps that would otherwise be done. The CGWB (2007) template for cost benefit analysis adopts the income from increased production rather than the net income after costs ( $28 \%$ of income in the current study), 
and the default value suggests crop irrigation requirement is $670-1,000 \mathrm{~mm} /$ year, which is somewhat larger than the $413 \mathrm{~mm} /$ year for the cropping mix in the current study. Hence, on balance, the default values in CGWB (2007) likely overestimate the benefits in comparison with the current study. However conservative default values for annual costs are likely to at least partially compensate, by including an annual interest expenditure of $10 \%$ of the capital cost, maintenance and repairs charges of $2.5 \%$, depreciation of civil works $5 \%$ and miscellaneous expenditure of $1 \%$. An example of percolation tanks in Baramati Taluka of Pune District, Maharashtra, is given that used a life time of 15 years and very high discount rate of $15 \%$ at an undeclared date, with an interest rate on loans of $11.5 \%$. The capital cost of $9 \mathrm{INR} / \mathrm{m}^{3}$ capacity, pre2007 , would considerably exceed the average capital costs for the current study at 7.9INR (in 2014) $/ \mathrm{m}^{3}$ capacity. The size of the tank evaluated was $130,000 \mathrm{~m}^{3}$, very similar to that of the Dharta check dam. For that example, the present value of costs exceeded the present value of benefits unless a $75 \%$ subsidy was applied to the capital cost. It is unclear whether capital costs as well as interest on capital are accounted for in this analysis, but it seems at odds with the BCR of 1.5 re-evaluated for the average of 149 check dams in the Baramati area, as shown in the preceding text.

Malik et al. (2014) followed a different approach, by interviewing 120 farmers with and without small private rainwater harvesting structures on their land in western Madhya Pradesh and recording the changes in reported crops and livestock. There was negligible change in kharif cropped area and livestock numbers, but a very substantial increase in cropped area in the rabi season followed construction of structures. In this area, of $\sim 800-\mathrm{mm}$ annual rainfall, irrigation water was drawn directly from farm water storages rather than by recharge to the aquifer and then extracting. Benefit cost ratios of 1.9 and 1.5 were found for alluvial and hard-rock areas respectively without a government subsidy. In hard-rock areas, the depth of excavation and hence impoundment depth was constrained. These structures occupied between 6 and $10 \%$ of a farmer's land area, and so it is not surprising that with evaporation losses and low use of water for irrigation in the kharif season, the available irrigation water would be less than detention capacity, so the benefit:cost ratio would be expected to be lower than that found for groundwater recharge structures in wadis found in the current study, where average recharge was 1.66 times detention capacity.

\section{Conclusions}

The results give some measures not previously reported and reveal some interesting observations that could be important for siting, design and maintenance of recharge structures. Firstly, the basic hydrologic studies over 3 years of four check dams with a total catchment area of 3,003 ha in southern Rajasthan revealed that the check dams contributed recharge that averaged $26 \mathrm{~mm} /$ year. This recharge equated to $3.3 \%$ of the average annual recorded rainfall $(779 \mathrm{~mm})$ over this period and $19 \%$ of crudely estimated runoff. Annual recharge from these four studied check dams was $0.78 \mathrm{Mm} 3 /$ year, and it equated to $8 \%$ of average rabi season water use over 2,330 ha of cropped area. The average annual recharge was 4 times the evaporative loss from the check dams, and 1.66 times the capacity of the check dams. The method of recharge calculation was shown to have low sensitivity to evaporation rate and the estimated WWIR, and was independent of the assumed weir coefficient and estimated runoff. Seasonal runoff volumes, where they could be measured accurately for check dams that did not spill in some years, were between 20 and $100 \%$ of the estimated values based on Strange's table values for the rainfalls received in those seasons.

Mean dry weather infiltration rate (MDWIR) across four check dams and 3 years was $27 \mathrm{~mm} /$ day. The value varies with season, and higher flow years had lower infiltration rates, largely due to hydraulic connection occurring between underlying groundwater and impounded water, which significantly reduced and in one case reversed, the hydraulic gradient from the check dam. At the peak of the 2016 monsoon season, some streams flowed continuously demonstrating groundwater discharge to some reaches upstream of check dams. Anecdotal evidence suggests there are variations between check dams and years in the rate of siltation, which is expected to reduce hydraulic conductivity and storage capacity and hence check dam effectiveness.

Scraping check dams manually appears to be much more effective in restoring MDWIR than mechanical scraping, where subsoil compaction appears to have negated the expected benefits of desilting. In this cohort, $2.9 \%$ of the capital costs were expended on average annually on maintenance. This was quite unevenly spread among sites and for one check dam there had been no maintenance in 22 years. It is recommended that a larger number of check dams need to have monitoring and pilot maintenance programs in order to refine these and to estimate a budget for effective maintenance of Rajasthan and India's existing recharge assets. The MDWIR calculation can be done by farmers through a citizen science activity (Jadeja et al. 2018; Daly et al. 2018) and this will help prioritize check dams for desilting.

Measuring groundwater levels adjacent to check dams helps to reveal whether a measured decline in infiltration rate is due to siltation or to hydraulic connection with groundwater. This information could be used to better inform siting, design and maintenance of check dams in catchments - for example, locating check dams outside areas of seasonal groundwater discharge would help to increase their cost-effectiveness.

The benefit:cost analysis method applied is similar to other approaches, except that it makes use of estimated recharge 
derived from robust daily water balance calculations, rather than estimating the areas likely to be effected by a check dam or attributing increases in income solely to new recharge structures. However, it does rely on an assumption that all the water recharged becomes accessible as irrigation water that results in increased crop production, and in this area, with 250 wells observed weekly over 3 years (Chinnasamy et al. 2018a), this assumption appears reasonable. The four check dams have an average unit cost of recharge of $0.56 \mathrm{INR} / \mathrm{m}^{3}$ and a crop production benefit based on the recorded crop mix, to calculate a unit benefit of $2.36 \mathrm{INR} / \mathrm{m}^{3}$ giving a benefit:cost ratio of 4.1. Even if a modest proportion of the volume of recharged water from check dams is recovered as irrigation water and increased crop production, these check dams would still be considered economically attractive. Further work is required to evaluate impacts of check dams on downstream communities to enable a catchment-wide benefit:cost ratio to be determined, which would be the most appropriate measure of economic impacts of check dams.

Acknowledgements The authors thank the following farmers: Rameshwar Lal Soni, Radheyshyam, Mittu Singh, and Devilal Gadri who undertook check dam monitoring in their role as Bhujal Jankaars. The authors are grateful to the Watershed Department and Irrigation Department of Rajasthan for providing information on costs of check dams and their maintenance and on areas, prices, costs of production and water use of each crop type grown in the catchment. This paper was advanced thanks to the International Centre of Excellence in Water Resources Management (ICEWaRM) Visiting Fellowships to Y. Dashora and P. Soni, enabling stays in Adelaide at Flinders University and CSIRO, respectively.

Funding information This research was conducted under the Managed Aquifer Recharge through Village-level Intervention (MARVI) project, which was funded by the Australian Centre for International Agricultural Research (as ACIAR Project No. LWR/2010/015).

Open Access This article is distributed under the terms of the Creative Commons Attribution 4.0 International License (http:// creativecommons.org/licenses/by/4.0/), which permits unrestricted use, distribution, and reproduction in any medium, provided you give appropriate credit to the original author(s) and the source, provide a link to the Creative Commons license, and indicate if changes were made.

\section{References}

Agoramoorthy G, Hsu MJ (2008) Small size, big potential: check dams for sustainable development. Environ Sci Policy Sustain Dev 50(4): $22-35$

Beernaerts I (2006) An evaluation framework for groundwater recharge enhancement systems for improved irrigated agriculture. MSc Thesis, Univ. of South Australia, Adelaide, Australia

Bouwer H (1978) Groundwater hydrology. McGraw-Hill, New York

Burke JJ, Moench M (2000) Groundwater and society: resources, tensions and opportunities - themes in groundwater management for the twenty-first century. UN Dept. of Economic and Social Affairs and the Institute for Social and Environmental Transition, New York

Chinnasamy P, Maheshwari B, Dillon P, Purohit R, Dashora Y, Soni P, Dashora R (2018a) Estimation of specific yield using water table fluctuations and cropped area in a hardrock aquifer system of Rajasthan, India. Agric Water Manag 202:146-155

Chinnasamy P, Muthuwatta L, Eriyagama N, Pavelic P, Lagudu S (2018b) Modelling the potential for floodwater recharge to offset groundwater depletion: a case study from the Ramganga basin, India. Sustain Water Resour Manag. https://doi.org/10.1007/ s40899-017-0168-6 or https://recharge.iah.org/swarm-vol-4-issue2-june-2018. Accessed 17 Jan 2019

CGWB (2000) Guide on artificial recharge to ground water. Central Ground Water Board, 59 pp. http://cgwb.gov.in/documents/ ArtificialRecharge-Guide.pdf. Accessed 17 Jan 2019

CGWB (2007) Manual on artificial recharge of ground water. Central Ground Water Board, 185 pp. http://cgwb.gov.in/documents/ Manual\%20on\%20Artificial\%20Recharge\%20of\%20Ground\% 20Water.pdf. Accessed 17 Jan 2019

Daly L, Maheshwari B, Dillon P (2018) MyWell: an app for monitoring groundwater levels, rainfall, water quality and check dam water levels at village level. Working paper, Researchgate. https://www. researchgate.net/publication/318460497_MyWell_An_App_for_ Monitoring_Groundwater_Levels_Rainfall_Water_Quality_and Checkdam_Water_Levels_at the Village_Level. Accessed $1 \overline{7}$ Jan 2019

Dakshinamurti C, Michael AM, Dastane NG (1971) Water recourses and their optimum utilization in agriculture. Proceeedings, Water Resources Symposium, Indian Institute of Science, Bangalore, India

Dashora Y, Dillon P, Maheshwari B, Soni P, Dashora R, Davande S, Purohit RC, Mittal HK (2018) A simple method using farmers' measurements applied to estimate check dam recharge in Rajasthan, India. Sustain Water Resour Manag 4(2):301-316. https://doi.org/10.1007/s40899-017-0185-5 or https://recharge.iah. org/thematic-issues-journals. Accessed 17 Jan 2019

Dastane NG, Singh M, Hukkeri SB, Vamadevan VK (1970) Review of work done on water requirement in India. Navbharat Prakashan Poona, 1970

Dillon PJ (1983) Artificial groundwater recharge: a case study in Maharashtra, India. Univ. of Adelaide, Civil Eng. Dept., General Report Series no. G15, 22 pp

Dillon PJ (1984) Ephemeral Stream-Aquifer Interaction. PhD Thesis, University of Adelaide, Australia

Dillon PJ, Liggett JA (1983) An ephemeral stream aquifer interaction model. Water Resour Res 19(3):621-626

Dillon P, Gale I, Contreras S, Pavelic P, Evans R, Ward J (2009) Managing aquifer recharge and discharge to sustain irrigation livelihoods under water scarcity and climate change. IAHS Publ 330, IAHS, Wallingford, UK, pp 1-12

Dillon P, Vanderzalm J, Sidhu J, Page D, Chadha D (2014) A water quality guide to managed aquifer recharge in India. CSIRO Land and Water and UNESCO Report of AusAID PSLP Project ROU 14476. https://publications.csiro.au/rpr/pub?pid=csiro:EP149116 or https://recharge.iah.org/files/2016/11/A-Water-Quality-Guide-toMAR-in-India-2014.pdf. Accessed 17 June 2018

Dillon P, Stuyfzand P, Grischek T, Lluria M, Pyne RDG, Jain RC, Bear J, Schwarz J, Wang W, Fernandez E, Stefan C, Pettenati M, van der Gun J, Sprenger C, Massmann G, Scanlon BR, Xanke J, Jokela P, Zheng Y, Rossetto R, Shamrukh M, Pavelic P, Murray E, Ross A, Bonilla Valverde JP, Palma Nava A, Ansems N, Posavec K, Ha K, Martin R, Sapiano M (2019) Sixty years of global progress in managed aquifer recharge. Hydrogeol J. 27 (1): 1-30. (Published on-line 7 Sept 2018) https://doi.org/10.1007/s10040-018-1841-z . Accessed 17 Jan 2019

Gale IN, Macdonald DMJ, Calow RC, Neumann I, Moench M, Kulkarni H, Mudrakartha S, Palanisami K, (2006) Managed aquifer recharge: an assessment of its role and effectiveness in watershed management. British Geological Survey Commissioned report CR/06/107 N, BGS, Keyworth, UK. http://nora.nerc.ac.uk/id/eprint/7453/. Accessed 17 Jan 2019 
Garg KK, Bharati L, Gaur A, George B, Acharya S, Jella K, Narasimhan B (2012) Spatial mapping of agricultural water productivity using the swat model in Upper Bhima Catchment, India. Irrig Drain 61(1): 60-79

Ghamarnia H, Miri E, Ghobadei M (2014) Determination of water requirement, single and dual crop coefficients of black cumin (Nigella sativa L.) in a semi-arid climate. Irrig Sci 32(1):67-76

Hussain I, Turral H, Molden D, Ahmad (2007) Measuring and enhancing the value of agricultural water in irrigated river basins. Irrig Sci 25(3):263-282

ICAR (2009) Handbook of agriculture. Indian Council of Agricultural Research, New Delhi. http://www.icar.org.in/files/forage-andgrasses.pdf. Accessed 17 Jan 2019

Inflation EU (2017) Worldwide inflation data. http://www.inflation.eu/ inflation-rates/india/historic-inflation/cpi-inflation-india.aspx. Accessed 17 Jan 2019

Jadeja Y, Maheshwari B, Packham R, Hakimuddin B, Purohit R, Thaker B, Dillon P, Oza S, Dave S, Soni P, Dashora, Y, Dashora R, Shah T, Gorsiya J, Katara P, Ward J, Kookana R, Singh PK, Chinnasamy P, Goradiya V, Prathapar S, Varua M, Chew M (2018) Managing aquifer recharge and sustaining groundwater use: developing a capacity building program for creating local groundwater champions. Sustain Water Resour Manag. https://doi.org/10.1007/s40899-018-0228-6 or https://recharge.iah.org/thematic-issues-journals. Accessed 17 Jan 2019

Kulkarni H, Shah M, Shankar PV (2015) Shaping the contours of groundwater governance in India. J Hydrol 4:172-192

Machiwal D, Jha MK, Singh PK, Mahnot SC, Gupta A (2004) Planning and design of cost-effective water harvesting structures for efficient utilization of scarce water resources in semi-arid regions of Rajasthan, India. Water Resour Manag 18(3):219-235

Machiwal D (2009) Hydraulic and geochemical characterization and groundwater prospect of hard-rock aquifer systems in Udaipur, Rajasthan. PhD Thesis, Indian Institute of Technology, Kharagpur, India

Maheshwari B, Varua M, Ward J, Packham R, Chinnasamy P, Dashora Y, Dave S, Soni P, Dillon P, Purohit RC, Hakimuddin, Shah T, Oza S, Singh PK, Prathapar S, Patel A, Jadeja Y, Thaker B, Kookana R, Grewal H, Yadav KK, Mittal HK, Chew M, Rao P (2014) The role of transdisciplinary approach and community participation in village scale groundwater management: insights from Gujarat and Rajasthan, India. Int Open Access J Water 6(6):3386-3408. http:// www.mdpi.com/journal/water/special_issues/MAR. Accessed 17 Jan 2019

Majumdar DK (2002) Irrigation water management: principles and practice. Prentice Hall, New Delhi. https://www.worldcat.org/title/ irrigation-water-management-principles-and-practice/oclc/ 772045685. Accessed 17 Jan 2017

Malik RPS, Giordanob M, Sharma V (2014) Examining farm-level perceptions, costs, and benefits of small water harvesting structures in Dewas, Madhya Pradesh. Agric Water Manag 131:204-211

Michael AM, Pandey SL (1970) Time your irrigation for top yields. Intensive Agriculture, May 1970

Mousavi SF, Rezai V (1999) Evaluation of scraping treatments to restore initial infiltration capacity of three artificial recharge projects in central Iran. Hydrogeol J 7(5):490-500

Patel SA (2002) Impact of groundwater recharge activities in Saurashtra. In: Annual Partners' Meet 2002. IWMI-Tata Water Policy Research Programme, Anand, India, $19 \mathrm{pp}$

Rajasthan Department of Agriculture (2017) Rajasthan agricultural statistics at a glance 2014-15. Directorate of Agriculture Rajasthan, Jaipur. http://www.agriculture.rajasthan.gov.in/content/agriculture/ en/Agriculture-Department-dep/agriculture-statistics.html. Accessed 17 Jan 2019

Rajasthan Ground Water Department (2008) Reappraisal of ground water resources of Udaipur District on 31.03.2007. Ground Water Department (GWD), Government of Rajasthan, Jodhpur, India

Shah T (2009) Taming the anarchy: Groundwater governance in South Asia. Resources for the Future, Washington, DC, and International Water Management Institute, Colombo, Sri Lanke

Shankar PV, Kulkarni H, Krishnan S (2011) India's groundwater challenge and the way forward. Econ Polit Wkly 46(2):7-45

Singh GB, Moolani MK (1969) Studies on the effect of fertilizers and irrigation levels on water use efficiency of raya (Brassica juncea). Proceedings ICAR Symposium, Water Management, Hisar, India

Subramanya K (2008) Engineering hydrology, 3rd edn. McGraw Hill, Tata, India, pp 155-162 